\title{
Directing a Non-Heme Iron(III)-Hydroperoxide Species on a Trifurcated Reactivity Pathway
}

Wegeberg, Christina; Lauritsen, Frants R.; Frandsen, Cathrine; Mørup, Steen; Browne, Wesley R.; Mckenzie, Christine J.

Published in:

Chemistry - A European Journal

Link to article, DOI:

10.1002/chem.201704615

Publication date:

2018

Document Version

Publisher's PDF, also known as Version of record

Link back to DTU Orbit

Citation (APA):

Wegeberg, C., Lauritsen, F. R., Frandsen, C., Mørup, S., Browne, W. R., \& Mckenzie, C. J. (2018). Directing a Non-Heme Iron(III)-Hydroperoxide Species on a Trifurcated Reactivity Pathway. Chemistry - A European Journal, 24(20), 5134-5145. https://doi.org/10.1002/chem.201704615

\section{General rights}

Copyright and moral rights for the publications made accessible in the public portal are retained by the authors and/or other copyright owners and it is a condition of accessing publications that users recognise and abide by the legal requirements associated with these rights.

- Users may download and print one copy of any publication from the public portal for the purpose of private study or research.

- You may not further distribute the material or use it for any profit-making activity or commercial gain

- You may freely distribute the URL identifying the publication in the public portal 


\title{
Coordination Chemistry | Hot Paper $\mid$
}

\section{(2) Directing a Non-Heme Iron(III)-Hydroperoxide Species on a Trifurcated Reactivity Pathway}

\author{
Christina Wegeberg, ${ }^{[a]}$ Frants R. Lauritsen, ${ }^{[a]}$ Cathrine Frandsen, ${ }^{[b]}$ Steen Mørup, ${ }^{[b]}$ \\ Wesley R. Browne, ${ }^{[c]}$ and Christine J. McKenzie ${ }^{*[a]}$ \\ In memory of Professor John J. McGarvey
}

\begin{abstract}
The reactivity of $\left[\mathrm{Fe}{ }^{\prime \prime \prime}(\text { tpena })\right]^{2+}$ (tpena $=N, N, N^{\prime}-$ tris(2-pyridylmethyl)ethylenediamine- $N^{\prime}$-acetate) as a catalyst for oxidation reactions depends on its ratio to the terminal oxidant $\mathrm{H}_{2} \mathrm{O}_{2}$ and presence or absence of sacrificial substrates. The outcome can be switched between: 1) catalysed $\mathrm{H}_{2} \mathrm{O}_{2}$ disproportionation, 2) selective catalytic oxidation of methanol or benzyl alcohol to the corresponding aldehyde, or 3) oxidative decomposition of the tpena ligand. A common mechanism is proposed involving homolytic $\mathrm{O}-\mathrm{O}$ cleavage in the detected transient purple low-spin $(S=1 / 2)$ $\left[\left(\text { tpenaH) } \mathrm{Fe}{ }^{\mathrm{III}} \mathrm{O}-\mathrm{OH}\right]^{2+}\right.$. The resultant iron(IV) oxo and hydrox-
\end{abstract}

yl radical both participate in controllable hydrogen-atom transfer (HAT) reactions. Consistent with the presence of a weaker $\sigma$-donor carboxylate ligand, the most pronounced difference in the spectroscopic properties of $[\mathrm{Fe}(\mathrm{OOH})$ (tpenaH) $]^{2+}$ and its conjugate base, $[\mathrm{Fe}(\mathrm{OO})(\mathrm{tpenaH})]^{+}, \mathrm{com}-$ pared to non-heme iron(III) peroxide analogues supported by neutral multidentate $\mathrm{N}$-only ligands, are slightly blueshifted maxima of the visible absorption band assigned to ligand-to-metal charge-transfer (LMCT) transitions and, corroborating this, lower Fe"II/Fe" redox potentials for the procatalysts.

\section{Introduction}

Oxygen-coordinated iron complexes, such as iron(II)- $\mathrm{O}_{2}$ (dioxygen), iron(III)- $\mathrm{O}_{2}$ (superoxido and peroxido), iron(III)-OOH (hydroperoxido), and iron(III)-OOR (alkylperoxido), along with high-valent iron(IV) and iron(V) oxides formed upon homolytic or heterolytic cleavage of the $\mathrm{O}-\mathrm{O}$ bond in these complexes, have been proposed as key catalytically competent intermediates in oxidations catalysed by heme ${ }^{[1,2]}$ and non-heme ${ }^{[3,4]}$ enzymes, as well as in synthetic model compounds. ${ }^{[3,5-8]}$ To date, the field of non-heme peroxido compounds has been largely dominated by systems employing neutral aminopyridyl chelating ligands. ${ }^{[6,8]}$ However, akin to the modulation of $\mathrm{O}_{2}$ activation by heme enzymes mediated by a donor ligand trans to

[a] C. Wegeberg, Prof. F. R. Lauritsen, Prof. C. J. McKenzie Department of Physics, Chemistry and Pharmacy

University of Southern Denmark, Campusvej 55 5230 Odense M (Denmark)

E-mail:mckenzie@sdu.dk

[b] Prof. C. Frandsen, Prof. S. Mørup

Department of Physics, Technical University of Denmark 2800 Kongens Lyngby (Denmark)

[c] Prof. W. R. Browne

Molecular Inorganic Chemistry, Stratingh Institute for Chemistry University of Groningen, Nijenborgh 4

9747 AG, Groningen (The Netherlands)

$\square$ Supporting information, including crystallographic tables as well as MIMS

(iD data and EPR and ${ }^{1} H$ NMR spectroscopy data, and the ORCID numbers for the authors of this article can be found under https://doi.org/10.1002/ chem. 201704615. the oxygen binding site, we can reasonably expect that the introduction of anionic oxygen donors into the coordination sphere of an iron ion will stabilize higher oxidation states. Concomitantly, the $\mathrm{O}-\mathrm{O}$ bond of peroxido ligands coordinated to the same iron centre will be weakened. This hypothesis is supported by the fact that many oxidation processes catalysed by non-heme iron $\mathrm{O}_{2}$-activating enzymes, such as Rieske dioxygenases, tetrahydropterin-dependent hydroxylases, and 2-oxoglutarate-dependent dioxygenases and hydroxylases, possess an active site consisting of two histidine residues and one carboxylate group from Asp or Glu (Scheme 1). The reaction pathways followed by these enzymes proceed through cleavage of the $\mathrm{O}-\mathrm{O}$ bond of peroxide/superoxide ligands derived from $\mathrm{O}_{2}$ to form high-valent iron-oxido species, followed by direct oxidation of a substrate by the generated non-heme iron(IV). ${ }^{[4,9]}$ Despite the biological precedence, the weakening of the $\mathrm{O}-\mathrm{O}$ bond of an iron-coordinated peroxido ligand by the proximity of a carboxylato group has, to our knowledge, not yet been evaluated through systematic studies in model complexes.

Iron(III)-hydroperoxido and -peroxido complexes based on neutral pentadentate (N5) aminopolypyridyl ligands with an ethylenediamine backbone as the supporting scaffold, $\mathrm{N}$-alkyl$N, N^{\prime}$-tris(2-pyridylmethyl)ethylenediamine (Rtpen; Scheme 2a) were the first systems for which peroxide derivatives were spectroscopically characterized, and these have been extensively studied. ${ }^{[10-18]}$ Typically, these are generated by the reaction of air-stable iron(II) precursor complexes with $\mathrm{H}_{2} \mathrm{O}_{2}$, a prerequisite for which is oxidation of the iron centre from the $\mathrm{Fe}^{\mathrm{I}}$ to the $\mathrm{Fe}^{\mathrm{III}}$ oxidation state prior to formation of the $\mathrm{Fe}^{\mathrm{III}}-\mathrm{OOH}$ 


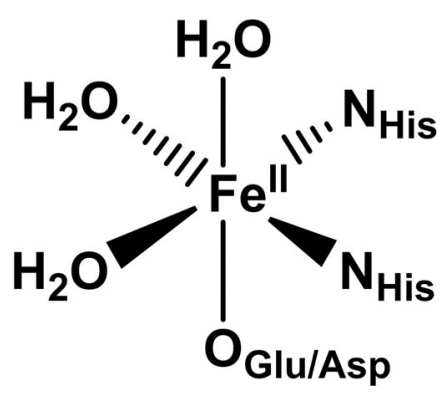

Scheme 1. Representation of the active site of $\mathrm{O}_{2}$-activating non-heme iron enzymes. The water molecules are labile, allowing coordination of substrates (e.g., $\mathrm{O}_{2}$, $\alpha$-ketoglutarate, tetrahydropterin, isopenicillin $\mathrm{N}$, taurine). (a)
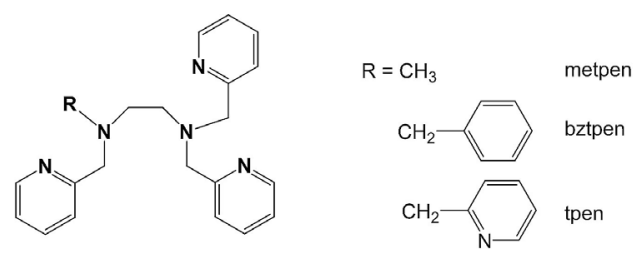

(b)
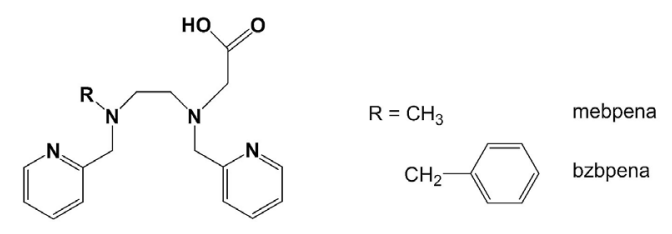

(c)

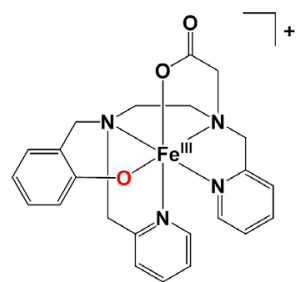

(d)

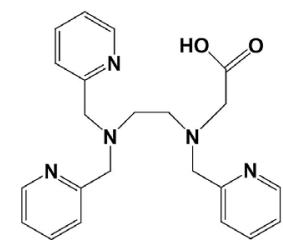

tpenaH

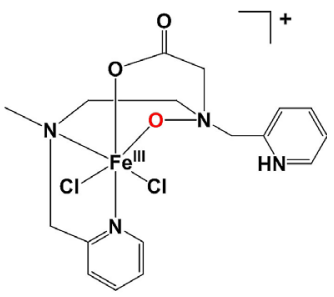

Scheme 2. Penta- and hexadentate ligands with ethylenediamine backbones for the preparation of iron(II/III/IV) peroxido and oxido complexes. a) Alkyland 2-methylpyridyl-containing N5 and N6 ligands, respectively. b) Alkyl and glycyl-containing $\mathrm{N} 4 \mathrm{O}$ (Rbpena). c) The iron(III) complexes of the oxygenated ligands obtained from the reactions of the iron(III) complexes of bzbpena and mebpena with $\mathrm{H}_{2} \mathrm{O}_{2}$. d) Amino-pyridyl glycyl N5O ligand tpena/tpenaH used in this work.

species. Analogously to one of the functions of the protein in non-heme enzymes, the presence of more than four donors in these supporting ligands serves to inhibit hydrolytic polymerization reactions. This must be particularly important in the study of biologically relevant iron(III) chemistry in the presence of terminal oxidants such as peroxides. Purple transient Fe"ll adducts, $\left[\mathrm{Fe}{ }^{\text {III }}(\mathrm{OOH})(\text { Rtpen })\right]^{2+}$, have been observed at room temperature with half-lives of up to $2 \mathrm{~h}$ following their initial formation over several seconds (i.e., after the $\mathrm{Fe}^{\text {II }}$ to $\mathrm{Fe}^{\text {III }}$ oxidation step and coordination of a deprotonated $\mathrm{H}_{2} \mathrm{O}_{2}$ ligand). Kinetic studies with [Fe"l'(Rtpen)] ${ }^{2+}$ precursors have indicated that the reaction is essentially instantaneous when the metal pre-oxidation step is circumvented. ${ }^{[11]}$ The Rtpen ligands also support iron(IV) oxo species. However, although their formation by homolytic cleavage of the $\mathrm{O}-\mathrm{O}$ bond of peroxide precursors has been proposed, it is important to note that such species have not actually been prepared using $\mathrm{H}_{2} \mathrm{O}_{2}$ as the terminal oxidant, but instead by reaction of the $\mathrm{Fe}^{\text {Il }}$ precursor with $\mathrm{PhIO}, \mathrm{m}$ $\mathrm{CPBA}$, or $\mathrm{ClO}^{-} .{ }^{[19]}$

Since monodentate carboxylate ligands are strong $\sigma$ donors, we reasoned that iron(III) precursor compounds suitable for the rapid preparation of peroxido adducts would be accessed if one of the pyridyl arms were to be substituted by a biomimetic glycinate group. Our initial foray using this strategy produced the $\mathrm{N} 4 \mathrm{O}$ ligands $\mathrm{N}$-R-N,N'-bis(2-pyridylmethyl)ethylenediamine- $N^{\prime}$-acetate (Rbpena), $R=$ methyl, benzyl (Scheme $2 \mathrm{~b}$ ), which indeed favoured the formation of iron(III) complexes. ${ }^{[18]}$ Reactions of these iron(III) complexes with $\mathrm{H}_{2} \mathrm{O}_{2}$ (and alkyl peroxides or $\mathrm{O}_{2}$ plus ascorbic acid) did not, however, produce detectable peroxide adducts, but instead oxygenation of the Rbpena ligands was observed. Aryl $\mathrm{C}-\mathrm{H}$ oxidation of bzbpena gave the iron(III) complex, in which an $\mathrm{O}$ atom was installed in the ligand, $N$-(2-oxidobenzyl)- $N, N^{\prime}$-bis(2-pyridylmethyl)ethylenediamine- $N^{\prime}$-acetate, and $\mathrm{O}$ atom insertion into an $\mathrm{Fe}-\mathrm{N}_{\text {amine }}$ bond provided an $\mathrm{N}$-oxide ligand, 2-((2-(methyl(pyridin-2-ylmethyl)amino)ethyl)-oxido(pyridin-2-ylmethyl)azanyl)acetate (Scheme 2c), for the iron(III) complex of the mepena ligand. These $\mathrm{O}$ atom $\mathrm{C}-\mathrm{H}$ and $\mathrm{Fe}-\mathrm{N}$ insertion reactions provide circumstantial evidence for the in situ formation of Fe" adducts and subsequent heterolytic $\mathrm{Fe}^{\mathrm{II}} \mathrm{O}-\mathrm{O}(\mathrm{H})$ bond cleavage to give putative high-valent $\mathrm{Fe}^{\mathrm{V}}$ oxo species capable of engaging in selective two-electron oxygen-atom transfer (OAT) reactions.

By adding a sixth heteroatom donor to replace the alkyl/aryl group in the $\mathrm{N} 4 \mathrm{O}$ Rbpena ligand systems, namely a third pyridine group to give the $\mathrm{N} 5 \mathrm{O}$ ligand $N, N, N^{\prime}$-tris(2-pyridylmethyl)ethylenediamine- $N$-acetate (tpena, Scheme $2 \mathrm{~d}$ ), we demonstrate here that the ability to generate detectable transient iron(III)-peroxide adducts is reinstated. In other words, behaviour similar to that observed for the iron(III) complexes of N5 Rtpen can be observed, and this contrasts with that for the iron(III) complexes of $\mathrm{N} 4 \mathrm{O}$ Rbpena. However, the Fe'II-OOH species formed from the tpena-iron complex has a significantly shorter lifetime than those derived from the corresponding Rtpen-based systems. At first sight, it might seem surprising that the ostensibly coordinatively saturated iron(III) precursor $[\mathrm{Fe}(\mathrm{tpena})]^{2+}$ can form heteroleptic complexes with co-ligand peroxide donors. However, we have previously demonstrated that external substrates can be selectively oxidized using the terminal oxygen-atom-transfer reagents iodosylbenzene and $\mathrm{N}$ morpholine- $\mathrm{N}$-oxide catalysed by $[\mathrm{Fe}(\text { tpena })]^{2+}$, and a sevencoordinated intermediate heteroleptic Fe ${ }^{\text {III-}-o x i d a n t ~ a d d u c t ~ w a s ~}$ isolated. ${ }^{[20,21]}$

Herein, we demonstrate the formation and characterization of the species [(tpenaH) $\left.\mathrm{Fe}^{\mathrm{III}}-\mathrm{OOH}\right]^{2+}$ and [(tpenaH) $\left.\mathrm{Fe}^{\prime \prime \prime}-\mathrm{OOO}\right]^{+}$ and show that the reactivity of these complexes is highly de- 


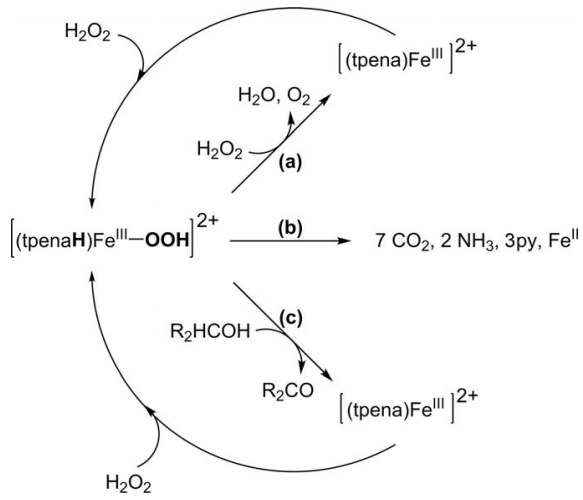

Scheme 3. Trifurcation of reactivity for the dihydrogen peroxide adduct of the iron(III) complex of tpena: a) catalytic $\mathrm{H}_{2} \mathrm{O}_{2}$ disproportionation, b) tpena degradation, c) catalytic alcohol oxidation to aldehydes.

pendent on opportunity (Scheme 3); specifically, we show that the complex elicits efficient disproportionation of $\mathrm{H}_{2} \mathrm{O}_{2}$, but crucially, the turnover catalytic conversion of $\mathrm{H}_{2} \mathrm{O}_{2}$ can be bifurcated $^{[22]}$ and in the presence of oxidizable substrates such as methanol or benzyl alcohol the oxidizing power is highly efficiently directed towards these substrates. A third path of oxidative chemistry has also been observed, namely destructive oxidation of the tpena ligand when the ratio of $\mathrm{H}_{2} \mathrm{O}_{2}$ to [Fe(tpena) $]^{2+}$ is low, for example, in the final stages of $\mathrm{H}_{2} \mathrm{O}_{2}$ disproportionation or if the concentration of substrate alcohol is lower than that of $\mathrm{H}_{2} \mathrm{O}_{2}$. The present study highlights the potential of the tpena ligand system in supporting various metal(III) coordination numbers (6 and 7), geometries, and spin states, as well as flexible stereochemistry in terms of the number of donor atoms furnished by tpenaH/tpena ( 5 or 6 ). The results emphasize the potential role played by a single biomimetic carboxylate donor moiety along with a second pendant pyridine base in the coordination sphere.

\section{Results and Discussion}

\section{$\mathrm{Fe}^{\mathrm{III}} / \mathrm{Fe}$ "l redox potentials for analogous iron complexes of $\mathrm{N} 50$ and $\mathrm{N} 6$ ligands}

Solutions of $\left[\mathrm{Fe}^{\mathrm{III}}(\mathrm{tpena})\right]^{2+}$ in acetonitrile are obtained by the dehydration of $[(\text { tpenaH }) \mathrm{Fe}(\mu-\mathrm{O}) \mathrm{Fe}(\mathrm{tpenaH})]^{4+}$ upon dissolution: ${ }^{[21]}[(\text { tpenaH }) \mathrm{Fe}(\mu-\mathrm{O}) \mathrm{Fe}(\text { tpenaH })]^{4+} \rightarrow 2[\mathrm{Fe}(\text { tpena) })]^{2+}+$ $\mathrm{H}_{2} \mathrm{O}$.

The cyclic voltammogram of $\left[\mathrm{Fe}^{\mathrm{III}}(\text { tpena) }]^{2+}\right.$ in acetonitrile shows a broad wave due to overlapping reversible $\mathrm{Fe}^{\mathrm{II}} / \mathrm{Fe}$ "I

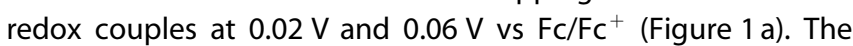
redox waves are associated with the high-spin $(S=5 / 2)$ mer-py ${ }_{3}^{-}$ $[\mathrm{Fe}(\text { tpena })]^{2+1+}$ and low-spin $\left(S={ }^{1} / 2\right)$ fac-py ${ }_{3}-[\mathrm{Fe}(\text { tpena })]^{2+1+}$ diastereoisomers (Figure $1 \mathrm{~b}$ ). Both the mer- $^{-\mathrm{py}_{3}}$ and fac-py ${ }_{3}$ isomers have been previously identified in both the solid and solution states by Mössbauer spectroscopy and in the frozen-solution state by EPR spectroscopy. ${ }^{[21]}$ The potentials are 0.38 and $0.34 \mathrm{~V}$ lower compared to that for the $\mathrm{Fe}^{\mathrm{III}} / \mathrm{Fe}$ "l couple of $[\mathrm{Fe}(\text { tpen })]^{3+/ 2+}\left(0.40 \mathrm{~V}\right.$ vs. $\mathrm{Fc} / \mathrm{Fc}^{+}$, tpen $=N, N, N^{\prime}, N^{\prime}$-tetrakis (2pyridylmethyl)ethylenediamine; Figure $1 \mathrm{~b}$ ). This result is con- (a)

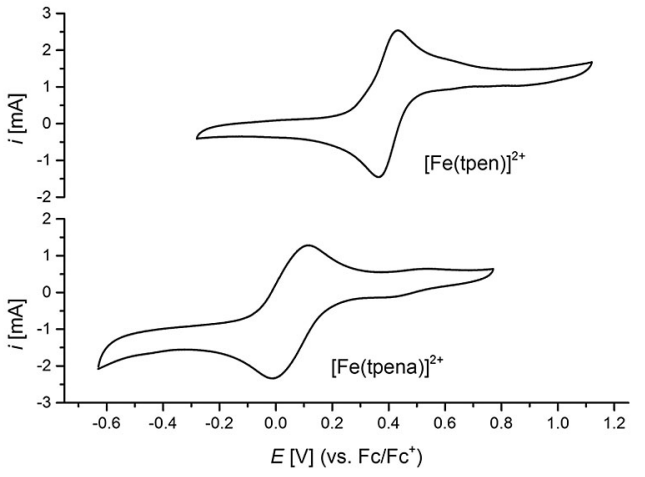

(b)

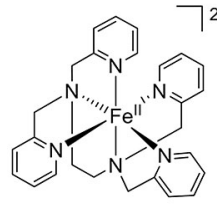

$[\mathrm{Fe}(\text { tpen })]^{2+}$

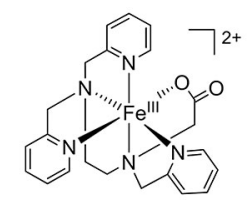

fac-[Fe(tpena) $]^{2+}$

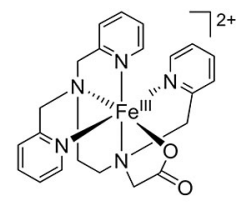

$\operatorname{mer}-[\mathrm{Fe}(\text { tpena })]^{2+}$
Figure 1. a) Cyclic voltammetry of $\left[\mathrm{Fe}^{\prime \prime}(\mathrm{tpen})\right]^{2+}\left(\mathrm{N}_{6}\right.$ ligand) and $\left[\mathrm{Fe}^{\text {III }}(\text { tpena) }]^{2+}\left(\mathrm{N}_{5} \mathrm{O}\right.\right.$ ligand) formed in situ from [Fe"(tpen)] $\left(\mathrm{ClO}_{4}\right)_{2}$ and $\left[(\right.$ tpenaH $) \mathrm{Fe}^{\text {III }}(\mu-\mathrm{O}) \mathrm{Fe}^{\prime \prime \prime}($ tpenaH $\left.)\right]\left(\mathrm{ClO}_{4}\right)_{4}$, respectively. $[\mathrm{Fe}]=0.5 \mathrm{~mm}$. Scan rate $0.1 \mathrm{~V} \mathrm{~s}^{-1}$ in $\mathrm{CH}_{3} \mathrm{CN}\left(0.1 \mathrm{M} \mathrm{TBAClO}{ }_{4}\right)$. b) Structures of [Fe(tpen)] ${ }^{2+}$, fac-[Fe(tpena) $]^{2+}$, and mer-[Fe(tpena) $]^{2+}$.

sistent with our expectation that the binding of a negatively charged carboxylate group in place of a pyridyl moiety will stabilize higher iron oxidation states. It is also consistent with the tendency, in the presence of air, for the tpen and neutral N5 Rtpen ligands to form iron(II) complexes, whereas iron(III) complexes are formed with tpena, irrespective of the oxidation state of the precursor iron starting salt $(+2$ or +3$)$. The minor redox wave at $0.46 \mathrm{~V}$ is due to the oxo-bridged precursor, $[($ tpenaH $) \mathrm{Fe}(\mu-\mathrm{O}) \mathrm{Fe}($ tpenaH $)]\left(\mathrm{ClO}_{4}\right)_{4} \cdot{ }^{[23]}$

\section{Reaction of $\mathrm{HCl}$ and $\mathrm{H}_{2} \mathrm{O}_{2}$ with [Fe(tpena) $]^{2+}$ to form [FeX- (tpenaH) $]^{2+}\left(\mathrm{X}=\mathrm{Cl}^{-}, \mathrm{OOH}^{-}\right)$}

Addition of concentrated $\mathrm{HCl}$ to solutions of either the brown complex $[(\text { tpenaH }) \mathrm{Fe}(\mu-\mathrm{O}) \mathrm{Fe}(\mathrm{tpenaH})]^{4+}$ (in water/EtOH) or of the red-orange complex $\left[\mathrm{Fe}(\text { tpena) }]^{2+}\right.$ (in acetonitrile) resulted in immediate formation of $[\mathrm{Fe}(\mathrm{Cl})(\mathrm{tpenaH})]^{2+}$, as manifested by a colour change to yellow, $\lambda_{\max }=312$ and $361 \mathrm{~nm}$ [Eqs. (1 a) and $(1 \mathrm{~b})$, respectively].

$[(\text { tpenaH }) \mathrm{Fe}(\mu-\mathrm{O}) \mathrm{Fe}(\text { tpenaH })]^{4+}+2 \mathrm{HCl} \rightarrow$

$2[\mathrm{Fe}(\mathrm{Cl})(\text { tpenaH })]^{2+}+\mathrm{H}_{2} \mathrm{O}$

fac $/$ mer- $[\mathrm{Fe}(\text { tpena })]^{2+}+\mathrm{HX} \rightarrow \mathrm{FeX}($ tpenaH $\left.)\right]^{2+} \quad \mathrm{X}=\mathrm{Cl}^{-}, \mathrm{OOH}^{-}$

The single-crystal X-ray structure of $[\mathrm{Fe}(\mathrm{Cl})(\mathrm{tpenaH})]-$ $\left(\mathrm{ClO}_{4}\right)_{2} \cdot \mathrm{EtOH} \cdot 2 \mathrm{H}_{2} \mathrm{O}$ (Figure $2 \mathrm{a}$ ) shows that the iron(III) ion is pentacoordinated by tpenaH, with a chlorido ligand occupying the sixth site. The pyridine arm attached to the same amine group, as the glycyl arm does not coordinate to the iron(III) 
(a)

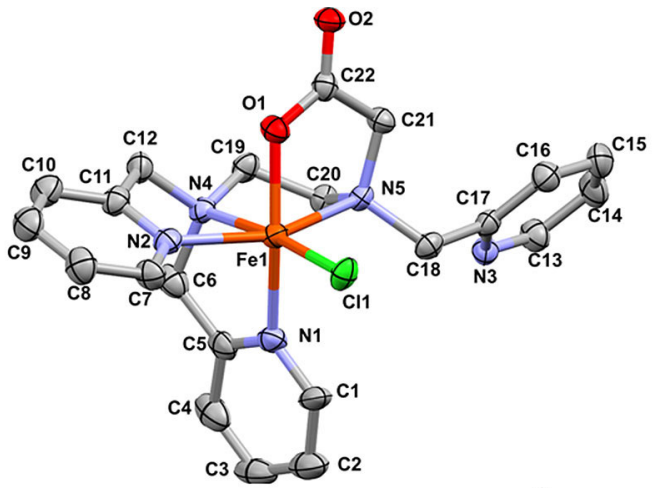

(b)

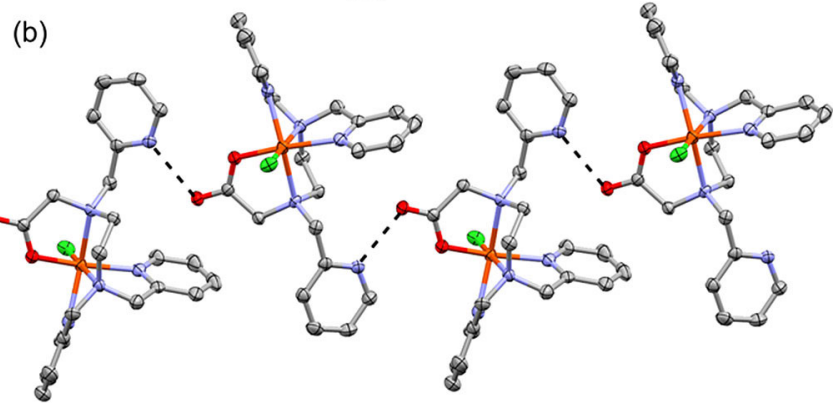

Figure 2. a) Crystal structure of $\left[\mathrm{Fe}(\mathrm{Cl})(\text { tpenaH) }]^{2+}\right.$. b) The hydrogen-bonded 1D helical chain of cations parallel to the $b$-axis. Thermal ellipsoids are drawn at $50 \%$ probability and the protons are omitted for clarity. The intermolecular hydrogen bond is shown with dashed lines $\left(\mathrm{C}=\mathrm{O} \cdots \mathrm{H}-\mathrm{N}_{\mathrm{py}} 1.845 \AA\right)$.

centre and is protonated. The structure is consistent with the chlorido ligand taking the position that the dangling pyridine had occupied in fac-[Fe(tpena) $]^{2+}$. The chlorido ligand is trans to the tertiary amine bearing the two methylpyridyl groups and cis to the carboxylato moiety. This structure is one $(A)$ of the six possible diastereoisomers depicted in Scheme 4. Intermolecular hydrogen bonding (Figure $2 \mathrm{~b}$ ) between the non-coordinated carboxylato oxygen and the protonated pyridine results in 1D homochiral chains of the cations parallel to the $b$ axis. These chains are separated by stacks of $\mathrm{ClO}_{4}{ }^{-}$anions, and water and ethanol molecules occupy pockets between the cationic chains. The solid-state Mössbauer spectrum of $[\mathrm{Fe}(\mathrm{Cl})$ (tpenaH)] $\left(\mathrm{ClO}_{4}\right)_{2} \cdot \mathrm{EtOH} \cdot 2 \mathrm{H}_{2} \mathrm{O}$ shows a broad singlet at $\delta=$ $0.46 \mathrm{~mm} \mathrm{~s}^{-1}$, consistent with a high-spin $(S=5 / 2)$ iron(III) complex. $[\mathrm{Fe}(\mathrm{Cl})($ tpenaH $)]\left(\mathrm{ClO}_{4}\right)_{2} \cdot \mathrm{EtOH} \cdot 2 \mathrm{H}_{2} \mathrm{O}$ is hygroscopic, and we have speculated that this could be associated with hydrolysis and loss of $\mathrm{HCl}$ to form the pseudo aquo complex $[\mathrm{Fe}(\mathrm{OH})$ $(\mathrm{tpenaH})]^{2+}$, which has been identified in aqueous solutions at low $\mathrm{pH}^{[23,24]}$
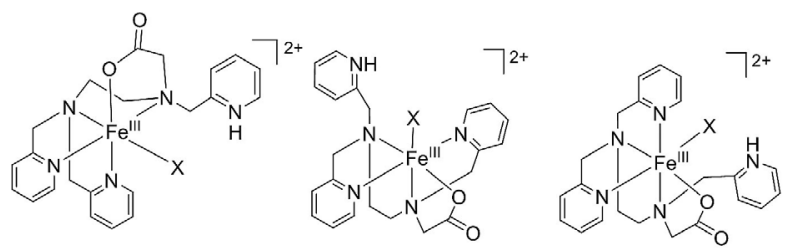

A

C

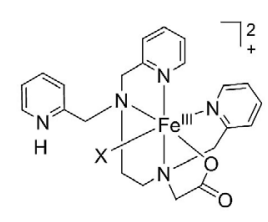

D

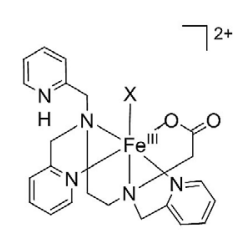

E

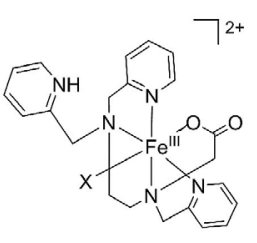

$\mathbf{F}$

Scheme 4. Possible diastereoisomers of $[\mathrm{Fe}(\mathrm{X})(\mathrm{tpenaH})]^{2+} ; \mathrm{X}=\mathrm{Cl}^{-}, \mathrm{OH}^{-}, \mathrm{OOH}^{-}$. 
(a)

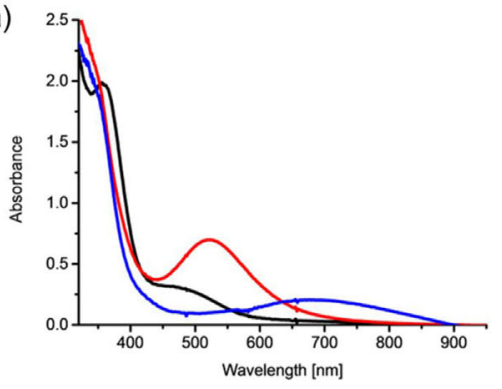

(c)

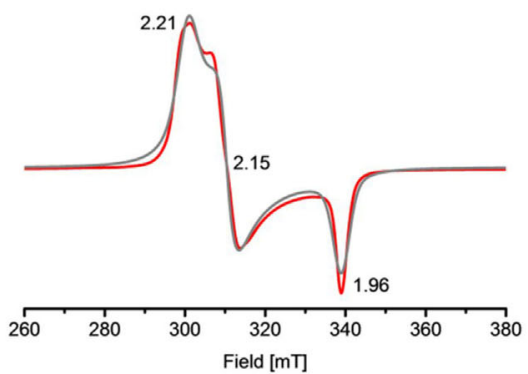

(b)

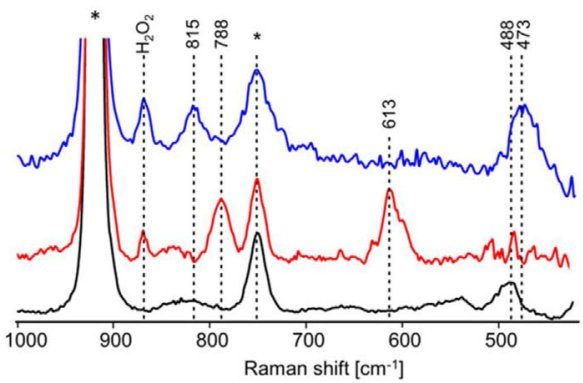

(d)

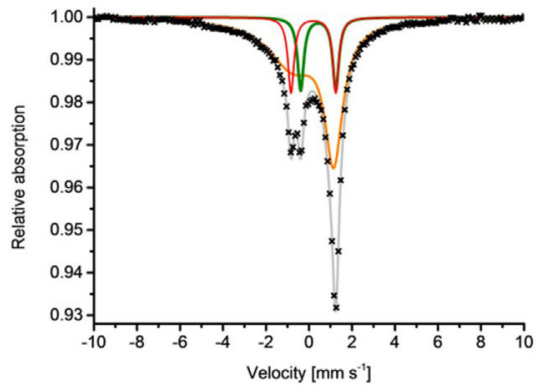

Figure 3. Solution-state spectroscopic characterization of $[\mathrm{Fe}(\mathrm{OOH})(\mathrm{tpenaH})]^{2+}$ and $[\mathrm{Fe}(\mathrm{OO})(\mathrm{tpenaH})]^{+}$. Colour coding: $[\mathrm{Fe}(\mathrm{tpena})]^{2+}$ in black, $[\mathrm{Fe}(\mathrm{OOH})-$ $(\text { tpenaH) }]^{2+}$ in red, $\left[\mathrm{Fe}(\mathrm{OO})(\text { tpenaH) }]^{+}\right.$in blue, $\left[\mathrm{Fe}_{2} \mathrm{O}(\mathrm{tpenaH})_{2}\right]^{4+}$ in green. Unidentified species depicted in orange (see text). The sum of the fitted data is coloured in grey. $[\mathrm{Fe}(\mathrm{OOH})(\mathrm{tpenaH})]^{2+}$ was generated by addition of 50 equiv of $\mathrm{H}_{2} \mathrm{O}_{2}$ to $\left[\mathrm{Fe}(\text { tpena) }]^{2+}\right.$ in $\mathrm{MeCN}$, and subsequent addition of 30 equiv of Et $\mathrm{E}_{3} \mathrm{~N}$ gave $\left[\mathrm{Fe}(\mathrm{OO})(\text { tpenaH) }]^{+}\right.$. a) UV/Vis absorption spectra $(\mathrm{RT},[\mathrm{Fe}]=1.5 \mathrm{~mm})$. b) Resonance Raman spectra $\left(-30^{\circ} \mathrm{C},[\mathrm{Fe}]=3 \mathrm{~mm}, \lambda_{\text {exc }}=532 \mathrm{~nm} \mathrm{for}[\mathrm{Fe}(\mathrm{OOH})-\right.$ $(\text { tpenaH) }]^{2+}$ and $\lambda_{\text {exc }}=691 \mathrm{~nm}$ for $\left[\mathrm{Fe}(\mathrm{OO})(\text { tpenaH) }]^{+}\right)$. All spectra were normalized to the solvent band at $750 \mathrm{~cm}^{-1} .^{*}=$ solvent bands. c) X-band EPR spectrum of $[\mathrm{Fe}(\mathrm{OOH})(\mathrm{tpenaH})]^{2+}$ (microwave frequency $9.314542 \mathrm{GHz}, 110 \mathrm{~K}$, $\left.\mathrm{Fe}\right]=2 \mathrm{~mm}$, fit in grey). d) Mössbauer spectrum of a mixture containing $[\mathrm{Fe}(\mathrm{OOH})-$ $($ tpenaH $)]^{2+}(14 \%),\left[\mathrm{Fe}_{2} \mathrm{O}(\text { tpenaH })_{2}\right]^{4+}(14 \%)$, and unidentified species $(72 \%)([\mathrm{Fe}]=2 \mathrm{mM})$.

responding to that observed in the crystal structure of the $\mathrm{HCl}$ adduct, Figure 2 (i.e., $\mathrm{A}$ in Scheme 4).

\section{Deprotonation of $[\mathrm{Fe}(\mathrm{OOH})(\mathrm{tpenaH})]^{2+}$}

The addition of $\mathrm{NEt}_{3}$ (30 equiv) to solutions of $\left[\mathrm{Fe}^{\mathrm{III}}(\mathrm{OOH})(\text { tpenaH })\right]^{2+}$ and excess $\mathrm{H}_{2} \mathrm{O}_{2}$ in acetonitrile results in an instant colour change from purple to blue and the appearance of a new absorption band at $675 \mathrm{~nm}$ (Figure $3 \mathrm{a}$, blue line). The lifetime of the new species is about $10 \mathrm{~min}$ at $0{ }^{\circ} \mathrm{C}$ when generated from 50 equiv of $\mathrm{H}_{2} \mathrm{O}_{2}$ and 30 equiv of $\mathrm{Et}_{3} \mathrm{~N}$. Immediate loss of the $\mathrm{Fe}-\mathrm{O}$ and $\mathrm{O}-\mathrm{O}$ bands of the end-on $\mathrm{Fe}^{\mathrm{III}}-\mathrm{OOH}$ in the Raman spectrum is accompanied by the appearance of the corresponding bands of a side-on peroxido complex at 473 and $815 \mathrm{~cm}^{-1}$ (Figure $3 \mathrm{~b}$ ), consistent with assignment of the species as [Fe" $(\mathrm{OO})(\mathrm{tpenaH})]^{+}$. The band positions are close to those reported for $\left[\mathrm{Fe}^{\prime \prime \prime}(\mathrm{OO})(\mathrm{tpen})\right]^{+}$and
$\left[\mathrm{Fe}^{\mathrm{III}}(\mathrm{OO})(\text { metpen })\right]^{+}$(Table 1). A high-spin signal $\left(g^{\text {eff }}=8.8,5.0\right.$, $4.3,4.2,3.5)$ appears in the EPR spectrum (Figure 4a). The Mössbauer spectrum (Figure $4 \mathrm{~b}$ ) of a sample composed of ${ }^{57} \mathrm{Fe}$-labelled [Fe'"(tpena) ${ }^{2+}$ shows a doublet with $\delta=$ $0.48 \mathrm{~mm} \mathrm{~s}^{-1}$ and $\Delta E_{\mathrm{Q}}=1.21 \mathrm{~mm} \mathrm{~s}^{-1}(47 \%)$, which is consistent with a high-spin $\mathrm{Fe}^{\mathrm{III}}$ species. The doublet due to $[\mathrm{Fe}(\mathrm{OOH})-$ $(\text { tpenaH) }]^{2+}$ is not observed, and the spectrum also shows the presence of a significant amount of the EPR-silent starting material $[(\text { tpenaH }) \mathrm{Fe}-\mathrm{O}-\mathrm{Fe}(\text { tpenaH })]^{4+} \quad\left(\delta=0.46 \mathrm{~mm} \mathrm{~s}^{-1}, \Delta E_{\mathrm{Q}}=\right.$ $\left.1.68 \mathrm{~mm} \mathrm{~s}^{-1}, 53 \%\right){ }^{[21]}$ It is interesting to note that this spectrum does not show the presence of unidentified iron complexes derived from the decomposition of tpena (see below) in contrast to the spectrum for $\left[\mathrm{Fe}(\mathrm{OOH})(\text { tpenaH) }]^{2+}\right.$ (Figure $3 \mathrm{~d}$ ). This lack of decomposition might suggest that the peroxide species is less reactive than the hydroperoxide species. This idea is supported by the fact that in order to acquire this clean spectrum it was necessary to add the base before the $\mathrm{H}_{2} \mathrm{O}_{2}$,
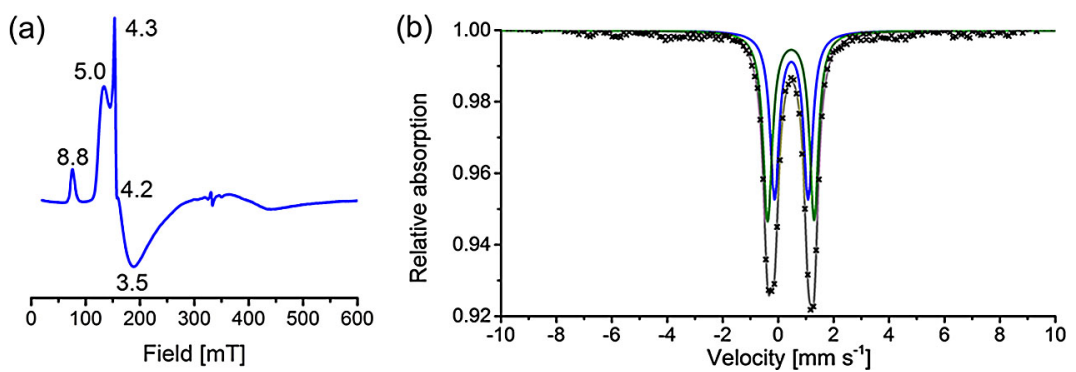

Figure 4. Frozen-solution-state spectroscopic characterization of $\left[\mathrm{Fe}(\mathrm{OO})\right.$ (tpenaH) ${ }^{+}$(blue). a) EPR spectrum (microwave frequency $9.315392 \mathrm{GHz}, 110 \mathrm{~K}, 2 \mathrm{~mm}$ $[\mathrm{Fe}(\mathrm{tpena})]^{2+}$ and 50 equiv of $\mathrm{H}_{2} \mathrm{O}_{2}$ followed by 30 equiv of $\left.\mathrm{Et}_{3} \mathrm{~N}\right)$. b) Mössbauer spectrum of a solution containing [Fe(OO)(tpenaH)] ${ }^{+}(\mathrm{blue}, 47 \%)$ and $\left[\mathrm{Fe}_{2} \mathrm{O} \text { (tpenaH) }\right]_{2}^{4+}$ (green, $53 \%$ ). Fitting in grey $\left(\left[{ }^{57} \mathrm{Fe}\right] 2 \mathrm{~mm}, 30\right.$ equiv of $\mathrm{Et}_{3} \mathrm{~N}$ followed by 50 equiv of $\mathrm{H}_{2} \mathrm{O}_{2}$ ). 


\begin{tabular}{|c|c|c|c|c|c|c|c|c|c|}
\hline & \multicolumn{3}{|c|}{ UV/Vis ${ }^{[a]}$} & \multicolumn{2}{|c|}{ rRaman $^{[a]}$} & \multicolumn{2}{|c|}{ Mössbauer ${ }^{[a]}$} & \multirow{2}{*}{$\begin{array}{l}\mathrm{EPR}^{[\mathrm{a}, \mathrm{b}]} \\
g \text {-values }\end{array}$} & \multirow[t]{2}{*}{$S$ Ref. } \\
\hline & $\begin{array}{l}\lambda_{\max } \\
{[\mathrm{nm}]}\end{array}$ & $\begin{array}{l}\varepsilon \\
{\left[\mathrm{M}^{-1} \mathrm{~cm}^{-1}\right]}\end{array}$ & $\begin{array}{l}v_{\mathrm{Fe}-\mathrm{O}} \\
{\left[\mathrm{cm}^{-1}\right]}\end{array}$ & $\begin{array}{l}v_{\mathrm{O}-\mathrm{O}} \\
{\left[\mathrm{cm}^{-1}\right]}\end{array}$ & Exp. conditions & $\begin{array}{l}\delta \\
{\left[\mathrm{mm} \mathrm{s}^{-1}\right]}\end{array}$ & $\begin{array}{l}\Delta E_{\mathrm{Q}} \\
{\left[\mathrm{mm} \mathrm{s}^{-1}\right]}\end{array}$ & & \\
\hline$\left[\mathrm{Fe}_{2}{ }_{2} \mathrm{O} \mathrm{O}(\text { tpenaH) })_{2}\right]^{4+}$ & 258 & & 830 & $\mathrm{n} / \mathrm{a}$ & solid state & 0.43 & 1.63 & silent & $\begin{array}{l}5 / 2[24] \\
\text { this work }\end{array}$ \\
\hline$f a c-\left[\mathrm{Fe}^{\prime \prime \prime}(\text { tpena) })\right]^{2+}$ & $360^{[c]}$ & $1330^{[\mathrm{c}]}$ & & & & 0.18 & 2.26 & $2.74,2.29,1.68$ & $1 / 2[21]$ \\
\hline mer-[Fe'"'(tpena) $]^{2+}$ & [c] & & & & & 0.25 & & 4.20 & $5 / 2[21]$ \\
\hline$\left[\mathrm{Fe}^{\mathrm{III}} \mathrm{Cl}(\text { tpenaH) }]^{2+}\right.$ & $\begin{array}{l}361 \\
312\end{array}$ & $\begin{array}{l}4150 \\
3940\end{array}$ & & & solid state & 0.46 & & & $5 / 2$ this work \\
\hline$\left[\mathrm{Fe} \mathrm{III}^{\prime \prime}(\mathrm{OOH})(\text { tpenaH) }]^{2+}\right.$ & 520 & $465^{[\mathrm{d}, f]}$ & 613 & 788 & $\begin{array}{l}\mathrm{MeCN},-30^{\circ} \mathrm{C}, \lambda_{\text {exc }} \\
532 \mathrm{~nm}\end{array}$ & 0.21 & $2.08^{[\mathrm{el}}$ & $2.21,2.15,1.96$ & $1 / 2$ this work \\
\hline$\left[\mathrm{Fe}^{\prime \prime \prime}(\mathrm{OOH})(\text { tpen) }]^{2+}\right.$ & 541 & $\begin{array}{l}900^{[f]} \\
200^{[g]}\end{array}$ & 617 & 796 & $\mathrm{MeOH}, \mathrm{RT}, \lambda_{\text {exc }} 568 \mathrm{~nm}$ & & & $2.22,2.15,1.97$ & $\begin{array}{l}1 / 2[14] \\
\text { this work }\end{array}$ \\
\hline$\left[\mathrm{Fe}^{\prime \prime \prime}(\mathrm{OOH})(\text { metpen })\right]^{2+}$ & 537 & $\begin{array}{l}1000^{[f]} \\
260^{[g]}\end{array}$ & 617 & 796 & $\mathrm{MeOH}, \mathrm{RT}, \lambda_{\text {exc }} 568 \mathrm{~nm}$ & 0.19 & $-2.01^{[\mathrm{e}]}$ & $2.19,2.12,1.95$ & $\begin{array}{l}1 / 2[10,14,15], \\
\text { this work }\end{array}$ \\
\hline$\left[\mathrm{Fe}^{\mathrm{III}}(\mathrm{OOH})(\mathrm{bztpen})\right]^{2+}$ & 542 & & & & & 0.17 & $-2.07^{[\mathrm{e}]}$ & $2.20,2.16,1.96$ & $1 / 2[11,16]$ \\
\hline$\left[\mathrm{Fe}^{\text {III }}(\mathrm{OO})(\text { tpenaH) }]^{+}\right.$ & 675 & $140^{[d]}$ & 473 & 815 & $\begin{array}{l}\mathrm{MeCN},-30^{\circ} \mathrm{C}, \lambda_{\text {exc }} \\
691 \mathrm{~nm}\end{array}$ & 0.48 & 1.21 & $\begin{array}{l}8.8,5.0,4.3,4.2 \\
3.5\end{array}$ & $5 / 2$ this work \\
\hline$\left[\mathrm{Fe}^{\prime \prime \prime}(\mathrm{OO})(\text { tpen) }]^{+}\right.$ & 755 & 450 & 470 & 817 & $\mathrm{MeOH}, \mathrm{RT}, \lambda_{\mathrm{exc}} 647 \mathrm{~nm}$ & & & $7.5,5.9$ & $5 / 2[14]$ \\
\hline$\left[\mathrm{Fe}^{\prime \prime \prime}(\mathrm{OO})(\text { metpen })\right]^{+}$ & 740 & 500 & 470 & 819 & $\mathrm{MeOH}, \mathrm{RT}, \lambda_{\mathrm{exc}} 647 \mathrm{~nm}$ & 0.64 & 1.37 & $7.5,5.9,4.4$ & $5 / 2[12,14,15]$ \\
\hline$\left[\mathrm{Fe}^{\mathrm{e}}(\mathrm{OO})(\mathrm{bztpen})\right]^{+}$ & 770 & & & & & 0.63 & 1.12 & $7.60,5.74$ & $5 / 2[11,16]$ \\
\hline \multicolumn{10}{|c|}{ 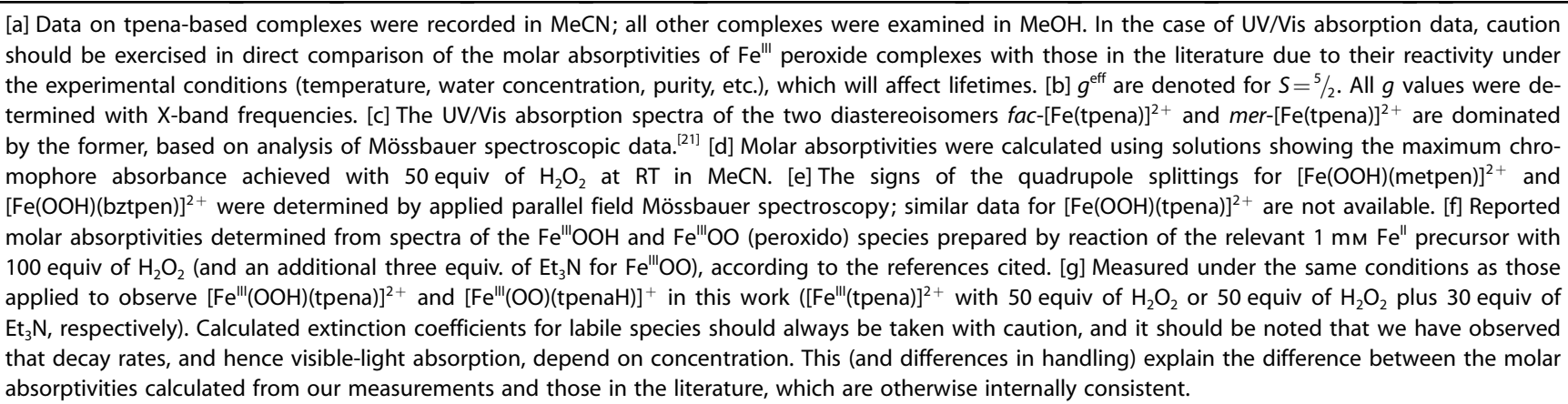 } \\
\hline
\end{tabular}

followed by rapid freezing in liquid $\mathrm{N}_{2}$. This protocol meant that the presumably more labile $[\mathrm{Fe}(\mathrm{OOH})(\text { tpenaH })]^{2+}$ did not get the chance to form in any significant concentration.

Spectroscopic data for $[\mathrm{Fe}(\mathrm{tpena})]^{2+}$ peroxide adducts are consistent with a side-on bound peroxide $\mathrm{Fe}^{\text {III }}$ complex in $\left[\mathrm{Fe}^{\mathrm{III}}(\mathrm{OO})(\mathrm{tpenaH})\right]^{+}$by comparison with iron complexes of Rtpen (Table 1, $\mathrm{R}=\mathrm{Me}, \mathrm{BzCH}_{2}, \mathrm{PyCH}_{2}$ ). This species is potentially intramolecularly (Scheme 5) or intermolecularly $\mathrm{H}$-bonded, with the solid-state structure of $\left[\mathrm{Cr}\left(\eta^{2}-\mathrm{OO}\right)(\mathrm{tpenaH})\right]^{+}$furnishing a structural analogue for the latter. ${ }^{[25]}$ The pendant pyridinium moiety of the tpenaH ligand is a second site available for deprotonation by a base, and [Fe"l'(OO)(tpena)] is a plausible product from the reaction of $\left[\mathrm{Fe}^{\prime \prime \prime}(\mathrm{OOH})(\mathrm{tpenaH})\right]^{2+}$ with two equivalents of base (Scheme 5). However, in this situation, the

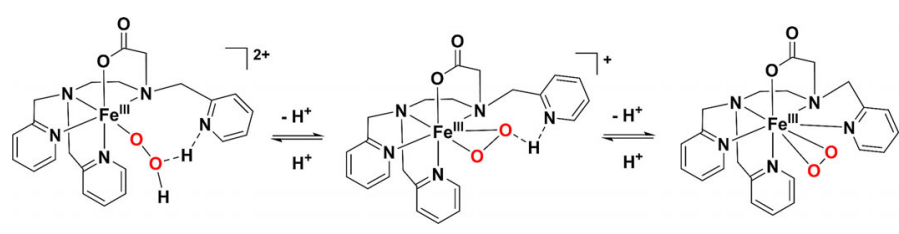

Scheme 5. Single- and double-deprotonation of $[\mathrm{Fe}(\mathrm{OOH})(\mathrm{tpenaH})]^{2+}$, leading to side-on peroxide coordination with speculative intramolecular hydrogen bonding. pyridine is expected to re-coordinate to the iron atom to form a seven-/eight-coordinated product for $\eta^{1}$ - and $\eta^{2}-\mathrm{OO}^{2-}$, respectively. This is not expected to be sterically too demanding, because the N-Fe-N angles for multidentate ligands with ethylenediamine backbones are generally less than $90^{\circ}$, thereby providing a relatively open face on the opposite side of the metal ion. Indeed, heptacoordination has been structurally characterized in the high-spin $d^{5}$ metal ion complexes $[\mathrm{Fe}(\mathrm{OIPh})($ tpena $)]\left(\mathrm{ClO}_{4}\right)_{2}{ }^{[20]}$ and $\left[\mathrm{Mn}\left(\mathrm{OH}_{2}\right)(\right.$ tpena $\left.)\right]\left(\mathrm{ClO}_{4}\right)_{2}{ }^{\left[{ }^{[26]}\right.}$ The relatively open face presented by tpena in these structures suggests that formation of a heteroleptic complex with an $\eta^{2}$ diatomic ligand is also a reasonable structure for the peroxido complex, especially since $\eta^{2}-\mathrm{OO}^{2-}$ ligands are no more sterically demanding than monodentate oxide $\left(\mathrm{O}^{2-}\right)$ ligands. ${ }^{[27]}$ Addition of further base leads to the formation of yellow solutions, with vigorous decomposition of $\mathrm{H}_{2} \mathrm{O}_{2}$ and ultimately decomposition of the complex (see below), such that the precise details of the protonation state cannot be readily determined experimentally.

Consideration of Table 1 shows that the most significant spectroscopic difference is that the $\mathrm{Fe}^{3+} \leftarrow \mathrm{OOH}^{-}$and $\mathrm{Fe}^{3+}$ $\leftarrow \mathrm{OO}^{2-} \mathrm{LMCT}$ bands for the end-on hydroperoxido and sideon peroxido Fe'l'-tpena complexes are at shorter wavelengths than those for the analogous Rtpen-based complexes. The 
$\lambda_{\max }$ for $[\mathrm{Fe}(\mathrm{OOH})(\text { tpenaH })]^{2+}$ is hypsochromically shifted by about $20 \mathrm{~nm}$, and the $\lambda_{\max }$ for $\left[\mathrm{Fe}^{\text {III }}(\mathrm{OO})(\mathrm{tpenaH})\right]^{+}$is shifted by 60,75 , and $95 \mathrm{~nm}$ compared to those reported for $\left[\mathrm{Fe}^{\mathrm{III}}(\mathrm{OO})(\mathrm{tpen})\right]^{+},\left[\mathrm{Fe}{ }^{\mathrm{III}}(\mathrm{OO})(\text { metpen})\right]^{+}$, and $\left[\mathrm{Fe} \mathrm{III}^{\mathrm{II}}(\mathrm{OO})(\text { bztpen })\right]^{+}$, respectively. The larger difference for the peroxido complexes may be related to the intramolecular $\mathrm{H}$-bonding.

\section{Competition between $\mathrm{H}_{2} \mathrm{O}_{2}$ disproportionation and ligand decomposition}

A large excess (20-50 equiv with respect to iron) of $\mathrm{H}_{2} \mathrm{O}_{2}$ is required to generate maximum steady-state concentrations of $[\mathrm{Fe}(\mathrm{OOH})(\mathrm{tpenaH})]^{2+}$ and $[\mathrm{Fe}(\mathrm{OO})(\mathrm{tpenaH})]^{+}$, under which conditions evolution of gas is observed. Analysis of the dissolved and evolved volatiles by means of membrane inlet mass spectrometry (MIMS) and head-space Raman spectroscopy (HS-RS; $\lambda_{\text {exc }}=532 \mathrm{~nm}$ ) confirmed that the gas evolved was predominantly $\mathrm{O}_{2}$. Addition of ${ }^{18} \mathrm{O}$-labelled water in a 1:1:1 ratio of $\mathrm{H}_{2} \mathrm{O}_{2}: \mathrm{H}_{2}{ }^{16} \mathrm{O}: \mathrm{H}_{2}{ }^{18} \mathrm{O}$ mixture, confirmed that the $\mathrm{O}_{2}$ evolved did not contain ${ }^{18} \mathrm{O}$ and hence that the two oxygen atoms in the evolved $\mathrm{O}_{2}$ were derived from $\mathrm{H}_{2} \mathrm{O}_{2}$. Thus, [Fe"'(tpena) $]^{2+}$ catalyses $\mathrm{H}_{2} \mathrm{O}_{2}$ disproportionation rather than a more demanding oxidation of water. ${ }^{[28]}$ To the best of our knowledge, $\mathrm{H}_{2} \mathrm{O}_{2}$ disproportionation catalysed by exclusively $\mathrm{N}$-donor Rtpen-supported iron(III) peroxides (Scheme $2 \mathrm{a} ; \mathrm{R}=\mathrm{CH}_{3}, \mathrm{PyCH}_{2}$ ) has not been reported. ${ }^{[10,11,17,29]}$ Since it seemed plausible that this reaction had simply been overlooked (because bubbles were not visible) in previous studies of the generation of non-heme Fe ${ }^{\text {III }}$ peroxides, we checked for this possible reaction in the present study by applying MIMS to monitor the reactions of $[\mathrm{Fe}(\mathrm{Cl})$ (metpen)] ${ }^{+}$and $\left[\mathrm{Fe}(\text { tpen) }]^{2+}\right.$ with 50 equiv of $\mathrm{H}_{2} \mathrm{O}_{2}$. We can verify that $\mathrm{O}_{2}$ evolution, and hence catalase activity, does not occur as a side reaction when these exclusively $\mathrm{N}$-donor ligands support the peroxide complexes.

In further contrast to the exclusively $\mathrm{N}$-donor-supported iron peroxide complexes, the hydroperoxido species, $[\mathrm{Fe}(\mathrm{OOH})$ $($ tpenaH $)]^{2+}$, is not regenerated by the addition of a second portion (50 equiv) of $\mathrm{H}_{2} \mathrm{O}_{2}$ after the cessation of $\mathrm{O}_{2}$ evolution, nor does catalytic $\mathrm{H}_{2} \mathrm{O}_{2}$ disproportionation resume. These observations indicate that either the catalyst is decomposed by $\mathrm{H}_{2} \mathrm{O}_{2}$ when the concentration of $\mathrm{H}_{2} \mathrm{O}_{2}$ is sufficiently low for competing $\mathrm{C}-\mathrm{H}$ oxidation of the tpena ligand to become kinetically competent, or the increase in water concentration (introduced with and formed from $\mathrm{H}_{2} \mathrm{O}_{2}$ ) drives the formation of a kinetically inert oxido-bridged species [(tpenaH) $\mathrm{Fe}(\mu-\mathrm{O}) \mathrm{Fe}-$ (tpenaH) $]^{4+} \cdot{ }^{[2,30]}$ To determine which of these pathways is pertinent, two equivalents of $\mathrm{H}_{2} \mathrm{O}_{2}$ were added to solutions of $[\mathrm{Fe}(\mathrm{tpena})]^{2+}$ in acetonitrile. A colour change to purple was not observed. Head-space infrared spectroscopy (HS-IRS), however, showed that $\mathrm{CO}_{2}$ was produced. The only carbon sources available for $\mathrm{CO}_{2}$ production were the solvent acetonitrile and/ or tpena. Monitoring both the $\mathrm{O}_{2}$ and $\mathrm{CO}_{2}$ releases by MIMS (Figure $5 \mathrm{a}$ ) following the addition of 50 equiv of $\mathrm{H}_{2} \mathrm{O}_{2}$ revealed that $\mathrm{O}_{2}$ was predominantly released in the early stages of the reaction. Quantitative analysis of the $\mathrm{CO}_{2}$ release by HS-IRS showed that approximately seven $\mathrm{CO}_{2}$ molecules per iron centre (Figure $5 \mathrm{~b}$ ) were produced. Increasing the amount of
$\mathrm{H}_{2} \mathrm{O}_{2}$ added did not result in an increase in $\mathrm{CO}_{2}$ formation, and it can therefore be concluded that the source of $\mathrm{CO}_{2}$ was degradation of tpena rather than oxidation of acetonitrile. Specifically, the $\mathrm{CO}_{2}$ must be derived from the aliphatic and carboxylate carbon atoms of tpenaH, as would be expected for aliphatic $\mathrm{C}-\mathrm{N}$ oxidative cleavage/hydrolysis reactions.

The changes in iron speciation after the addition of 50 equiv of $\mathrm{H}_{2} \mathrm{O}_{2}$ were monitored by UV/Vis absorption, Raman, EPR, and Mössbauer spectroscopies. The band at $520 \mathrm{~nm}$ due to the purple $\left[\mathrm{Fe}^{\text {III }}(\mathrm{OOH})(\text { tpenaH) }]^{2+}\right.$ chromophore decayed completely, and then a new and more intense band appeared at $469 \mathrm{~nm}$ (Figure 6a). The absence of an isosbestic point suggests that the conversion between these iron-based chromophores involves relatively long-lived intermediates that do not absorb in the visible region. Time-resolved head-space FTIR and UV/Vis absorption data indicated that the growth of the band at $469 \mathrm{~nm}$ was concomitant with the release of $\mathrm{CO}_{2}$ and the consequent growth of the absorbance at $2360 \mathrm{~cm}^{-1}$ in the HS-IR spectra. A fit of an EPR spectrum recorded from a reac-

(a)
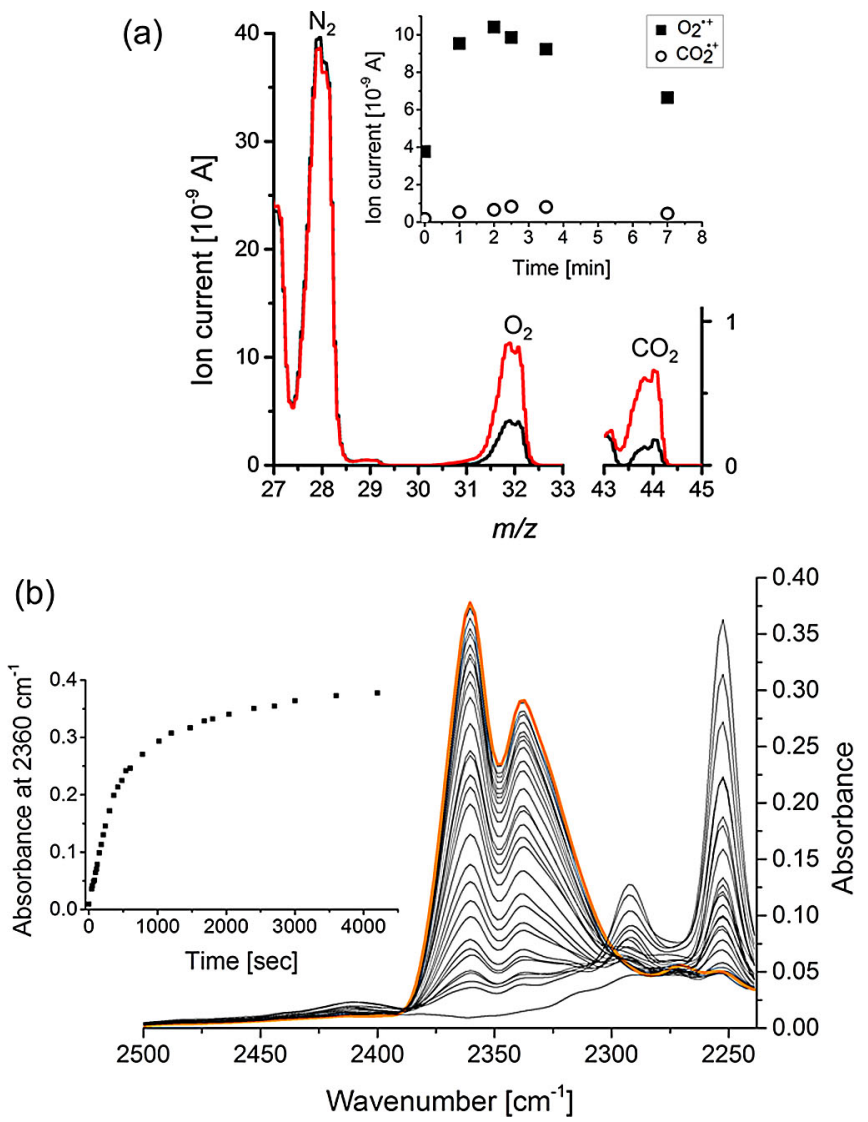

Figure 5. Detection of $\mathrm{O}_{2}$ and $\mathrm{CO}_{2}$ release. a) MIMS spectra of [Fe(tpena)] ${ }^{2+}$ $\left(0.5 \mathrm{~mm}\right.$ in acetonitrile) (black) and $2 \mathrm{~min}$ after addition of 50 equiv of $\mathrm{H}_{2} \mathrm{O}_{2}$ (red). $m / z 33-43$ is omitted due to dominating intense MeCN signals (full spectrum: Supporting Information Figure S1). Inset: Time dependence of the ion current for the ions $\mathrm{O}_{2}{ }^{+}(\mathrm{m} / \mathrm{z} 32)$ and $\mathrm{CO}_{2}{ }^{+}(\mathrm{m} / \mathrm{z} 44)$. b) Time-resolved head-space FTIR spectroscopy showing evolution of $\mathrm{CO}_{2}$ upon reaction of [Fe(tpena) $]^{2+}(2 \mathrm{~mm})$ with 50 equiv of $\mathrm{H}_{2} \mathrm{O}_{2}$. Inset: Time dependence of absorbance at $2360 \mathrm{~cm}^{-1}$. The acetonitrile bands at 2253 and $2292 \mathrm{~cm}^{-1}$ settle over time, concomitant with the decrease of effervescence due to both $\mathrm{CO}_{2}$ and $\mathrm{O}_{2}$. 
(a)

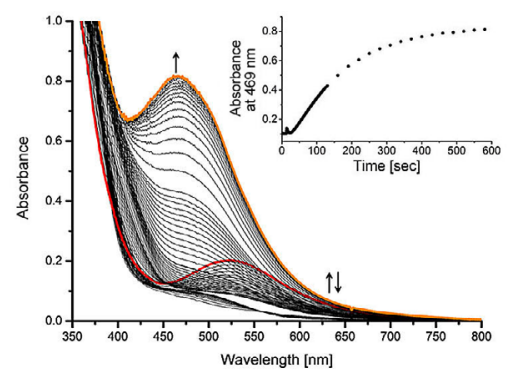

(b)

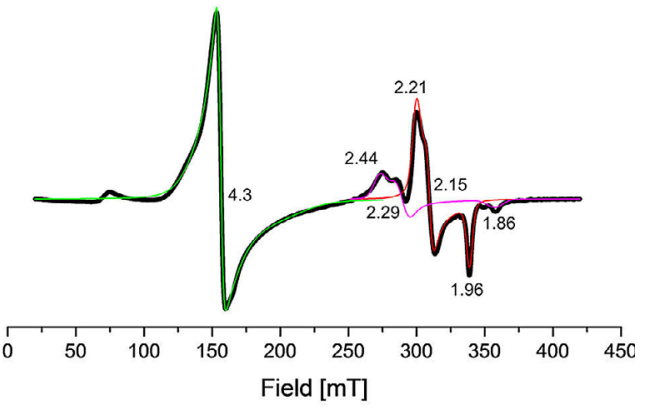

(c)

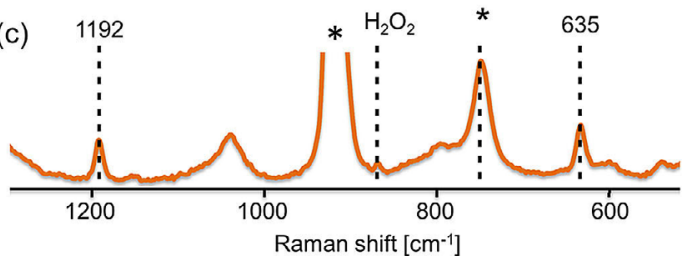

Figure 6. Time-resolved conversion of $\left[\mathrm{Fe}^{\prime \prime \prime}(\mathrm{OOH})(\mathrm{tpenaH})\right]^{+}$(red) to a lowspin $\mathrm{Fe}^{\prime \prime}$ species (orange) with the addition of 50 equiv of $\mathrm{H}_{2} \mathrm{O}_{2}$. a) UV/Vis absorption spectroscopy. [Fe] $=0.5 \mathrm{~mm}$. b) EPR spectrum recorded $2 \mathrm{~min}$ after the addition of $\mathrm{H}_{2} \mathrm{O}_{2}$ (black). Fitted data of $\left[\mathrm{Fe}(\mathrm{OOH})(\text { tpenaH) }]^{2+}\right.$ (red), a lowspin iron(III) species (pink, $g=2.44,2.29,1.86$ ), and a high-spin iron(III) species (green, $g^{\text {eff }}=4.3$ ). See Supporting Information Figure S3 for a summarized fit. c) Resonance Raman spectrum $\left(\lambda_{\text {exc }}=532 \mathrm{~nm}\right.$ ) recorded after the appearance of the absorption band at $469 \mathrm{~nm}$. $[\mathrm{Fe}]=1 \mathrm{~mm},{ }^{*}=$ solvent bands.

tion mixture frozen at $110 \mathrm{~K}$ at $2 \mathrm{~min}$ after mixing of 50 equiv of aqueous $\mathrm{H}_{2} \mathrm{O}_{2}$ with [Fe(tpena) $]^{2+}$ showed three overlapping signals: a residual rhombic signal assigned to $[\mathrm{Fe}(\mathrm{OOH})$ $($ tpenaH $)]^{2+}(g=2.21,2.15,1.96)$, a second broad rhombic signal assigned to an unknown low-spin iron(III) species at $g=$ $2.44,2.29,1.86$, and a signal at $g^{\text {eff }}=4.3$ due to an unknown high-spin iron(III) species (Figure $6 \mathrm{~b}$ ). It is important to note, however, that all of these species appeared with significantly lower signal intensities compared to that for $[\mathrm{Fe}(\mathrm{OOH})$ (tpenaH) $]^{2+}$ recorded from a sample that was frozen seconds after mixing (Figure $3 \mathrm{c}$ ). A series of spectra was recorded from the sample by allowing it to repeatedly warm to room temperature and then re-freezing it for EPR spectral acquisition in order to provide snapshots of the formation and disappearance of the aforementioned signals. A final spectrum was recorded after the solution had been left to stand for $2 \mathrm{~h}$ at room temperature. This showed that only a trace amount of the high-spin Fe ${ }^{\text {III }}$ signal remained, with the loss of all other signals. The Mössbauer spectrum recorded on the mixture containing $[\mathrm{Fe}(\mathrm{OOH})(\mathrm{tpenaH})]^{2+}$ (Figure $3 \mathrm{~d}$ ) shows, along with signals for $[\mathrm{Fe}(\mathrm{OOH})(\text { tpenaH })]^{2+}$ (red) and $\left[\mathrm{Fe}_{2} \mathrm{O}(\text { tpenaH })_{2}\right]^{4+}$ (green) a large area ascribed to one or more unidentified species. For simplicity, this was fitted to a broad asymmetric dou- blet with $\delta \approx 0.20 \mathrm{~mm} \mathrm{~s}^{-1}$ and $\Delta E_{\mathrm{Q}} \approx 1.90 \mathrm{~mm}^{-1}$ (72\%, orange fit). Such asymmetric doublets are commonly seen in spectra of high-spin iron(III) species with paramagnetic relaxation times on the order of a nanosecond. The low intensity of the signal in corresponding EPR spectra suggests that the electron spin relaxation in this dominant non-integer spin component is too rapid for the EPR timescale. Other potential decomposition products, integer spin $\mathrm{Fe}^{\mathrm{II}}$ and $\mathrm{Fe}^{\mathrm{IV}}$ monomers and the strongly anti-ferromagnetically coupled starting material, $\left[\mathrm{Fe}_{2} \mathrm{O}(\text { tpenaH })_{2}\right]^{4+}$, are expected to be EPR silent. Bands at $v=$ 634, 1192, and $2094 \mathrm{~cm}^{-1}$ appeared in the Raman spectrum $\left(\lambda_{\text {exc }}=532 \mathrm{~nm}\right)$ of equivalently treated solutions (Figure $6 \mathrm{c}$ ). The band at $v=2094 \mathrm{~cm}^{-1}$ is consistent with the presence of Fe"-coordinated acetonitrile. ${ }^{[31]} \mathrm{A}{ }^{1} \mathrm{H}$ NMR spectrum of the reaction mixture in $\mathrm{CD}_{3} \mathrm{CN}$ recorded after $16 \mathrm{~h}$ (and hence coinciding with the presence of the EPR-silent species with an absorption at $469 \mathrm{~nm}$ showed the characteristic signal of $\mathrm{NH}_{3}$ (three resonances of equal intensity centred at $\delta=6.61 \mathrm{ppm}, J_{14 \mathrm{~N}-1 \mathrm{H}}=$ $52 \mathrm{~Hz}$; Supporting Information, Figure S2). This demonstrated that the production of $\mathrm{NH}_{3}$ occurred concomitantly with the production of tpenaH-derived $\mathrm{CO}_{2}$. The signals remaining in the aromatic region (7-9 ppm) suggested that the pyridine groups remained intact. Positive- and negative-ion ESI-MS did not provide evidence for the formation of a complex with pyridine ligands that might be associated with the species at $469 \mathrm{~nm}$. Indirectly, however, the ESI-MS data provide further evidence that all of the aliphatic $\mathrm{C}$ atoms of the ligands were converted into $\mathrm{CO}_{2}$ through the absence, for example, of picolinato complexes that have previously been observed to form through the reaction of aminopyridyl-metal complexes with peroxides. ${ }^{[32]}$ Overall, the data lead to the conclusion that reaction of $[\mathrm{Fe} \text { (tpena) }]^{2+}$ with a large excess of $\mathrm{H}_{2} \mathrm{O}_{2}$ results primarily in $\mathrm{H}_{2} \mathrm{O}_{2}$ disproportionation, but is accompanied by concurrent oxidative decay of the tpena ligand, which occurs primarily when the concentration of $\mathrm{H}_{2} \mathrm{O}_{2}$ is low. A mixture of heteroleptic iron(II) complexes of pyridine, ammonia, and/or acetonitrile ligands is ultimately formed through the oxidative decomposition of [Fe"'(tpena) $]^{2+}$.

\section{Catalytic alcohol oxidation overrides catalase activity and ligand decomposition}

In stark contrast to the reactions of $\left[\mathrm{Fe}^{\prime \prime}(\mathrm{Cl})(\text { Rtpena) }]^{+}\right.$with excess $\mathrm{H}_{2} \mathrm{O}_{2}$ in methanol, ${ }^{[10,11,17]}$ the addition of 50 equiv of $\mathrm{H}_{2} \mathrm{O}_{2}$ to solutions of [Fe'"(tpena) ${ }^{2+}$ in methanol does not give rise to detectable amounts of purple $\left[\mathrm{Fe} \mathrm{e}^{\text {III }}(\mathrm{OOH})(\mathrm{tpenaH})\right]^{2+}$. This is because methanol is oxidized. Analysis using the Hantzsche reaction ${ }^{[33]}$ and UV/Vis absorption spectroscopy showed that formaldehyde was produced in approximately $35 \%$ yield based on the initial $\mathrm{H}_{2} \mathrm{O}_{2}$ concentration. Thus, the activation of $\mathrm{H}_{2} \mathrm{O}_{2}$ by [Fe'"(tpena) $]^{2+}$ can be directed to perform substrate oxidation. This observation inspired us to examine a more readily oxidizable substrate, benzyl alcohol, in acetonitrile (bond dissociation energies for $\mathrm{H}-\mathrm{CH}_{2} \mathrm{OH}$ and $\mathrm{H}-\mathrm{CH}(\mathrm{OH}) \mathrm{Ph}$ are 96 and $79 \mathrm{kcal} \mathrm{mol}^{-1}$, respectively $\left.{ }^{[34]}\right)$. The addition of 50 equiv of $\mathrm{H}_{2} \mathrm{O}_{2}$ to [ $\mathrm{Fe}(\text { tpena) }]^{2+}$ in the presence of 500 equiv of benzyl alcohol did not result in either $\mathrm{O}_{2}$ or $\mathrm{CO}_{2}$ evolution, and hence 
neither $\mathrm{H}_{2} \mathrm{O}_{2}$ disproportionation nor tpena decomposition occurred. In contrast to the reactions performed in methanol, under these conditions, $\left[\mathrm{Fe}^{\prime \prime \prime}(\mathrm{OOH})(\mathrm{tpenaH})\right]^{2+}$ was observed spectroscopically due to the lower concentration of the alcohol substrate. The addition of a second portion of $\mathrm{H}_{2} \mathrm{O}_{2}$ (50 equiv) resulted in reappearance of the absorption band of $\left[\mathrm{Fe}^{\mathrm{III}}(\mathrm{OOH})(\mathrm{tpenaH})\right]^{2+}$ with the same intensity as after the first addition (Figure 7). Continued batchwise addition of $\mathrm{H}_{2} \mathrm{O}_{2}$

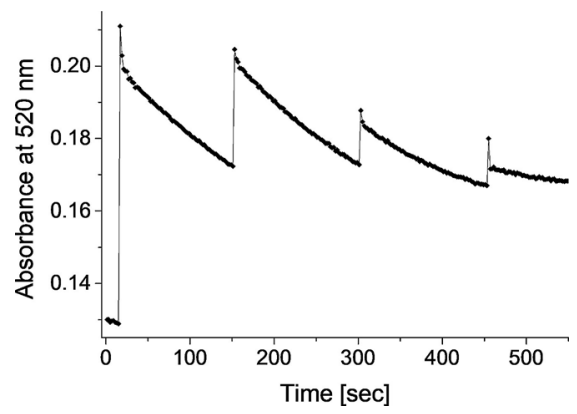

Figure 7. Time dependence of the absorbance at $520 \mathrm{~nm}$ in the presence of 500 equiv of $\mathrm{PhCH}_{2} \mathrm{OH}([\mathrm{Fe}]=0.5 \mathrm{~mm}$ ). The batchwise addition of 50 equiv of $\mathrm{H}_{2} \mathrm{O}_{2}$ causes jumps in the absorbance due to formation of the $\mathrm{Fe}^{\mathrm{III}}-\mathrm{OOH}$ intermediate.

eventually led to decomposition of the ligand, that is, the band at $469 \mathrm{~nm}$ intensified and the purple colour, due to $\left[\mathrm{Fe}^{\mathrm{III}}(\mathrm{OOH})(\mathrm{tpenaH})\right]^{2+}$, was lost. Thus, tpenaH oxidation competes with alcohol oxidation and the presence of a large excess of alcohol, or its use as the solvent delays the onset of ligand oxidation. ${ }^{1} \mathrm{H}$ NMR spectroscopic analysis showed, after five additions of 50 equiv of $\mathrm{H}_{2} \mathrm{O}_{2}$ over $10 \mathrm{~min}, 50 \%$ conversion of benzyl alcohol to benzaldehyde and hence near-stoichiometric conversion with respect to the oxidant. A control reaction in the absence of $\left[\mathrm{Fe}(\text { tpena) }]^{2+}\right.$ showed that, under otherwise identical conditions, benzyl alcohol was oxidized by $\mathrm{H}_{2} \mathrm{O}_{2}$ with only $32 \%$ conversion after $20 \mathrm{~h}^{[35]}$

\section{Mechanistic considerations}

The reaction of $\left[(\text { tpenaH)Fe-O-Fe(tpenaH) }]^{4+}\right.$ with $\mathrm{Ce}^{\mathrm{IV}}$ in water produces the iron(IV) oxo complex, $\left[\mathrm{Fe}^{\mathrm{IV}}(\mathrm{O})(\mathrm{tpenaH})\right]^{2+},{ }^{[24]}$ and recently we have generated this same species electrochemically, also in water. ${ }^{[23]}$ In both of these studies, we demonstrated $\left[\mathrm{Fe}^{\mathrm{IV}}(\mathrm{O})(\mathrm{tpenaH})\right]^{2+}$ to be a promiscuous oxidant in the absence of hydroxyl radicals. It attacks a broad range of $\mathrm{C}-\mathrm{H}$ bonds by hydrogen-atom transfer. Thus, $\left[\mathrm{Fe}^{\mathrm{IV}}(\mathrm{O})(\text { tpenaH })\right]^{2+}$ displays radical character. Calculations by Faponle et al. show that $\left[\mathrm{Fe}^{\mathrm{IV}}=\right.$ $\mathrm{O}$ (metpen) $]^{2+}$ can be generated by homolytic cleavage of $[\mathrm{Fe}(\mathrm{OOH})(\text { metpen })]^{2+}$, and it is the $\mathrm{Fe}^{\mathrm{IV}}$ oxo species that reacts with substrates. ${ }^{[36]}$ This reaction has been demonstrated in the gas phase. ${ }^{[1]]}$ However, the phase of the reaction medium (and second coordination sphere) is likely to tune the $\mathrm{O}-\mathrm{O}$ bondcleavage reaction. With these facts in mind, we propose that the $\mathrm{H}_{2} \mathrm{O}_{2}$ activation and reactivity described in the present study can be rationalized in terms of homolytic $\mathrm{O}-\mathrm{O}$ bond cleavage of the hydroperoxide ligand in $\left[\mathrm{Fe}^{\mathrm{III}}(\mathrm{OOH})(\mathrm{tpenaH})\right]^{2+}$.
This reactivity is in contrast to the behaviour of $\mathrm{Fe}^{\mathrm{III}}-\mathrm{OOH}$ based on neutral N5 donor systems. In fact, peroxide dissociation $^{[17,29]}$ is a highly competitive pathway for the decomposition of (N5)Fe"l'-OOH species. It can thus be concluded that for the iron-tpena system, homolytic $\mathrm{O}-\mathrm{O}$ bond cleavage occurs in $[\mathrm{Fe} \text { "l' }(\mathrm{OOH})(\text { tpenaH })]^{2+}$, resulting in the formation of $\left[\mathrm{Fe}^{\mathrm{IV}}(\mathrm{O})(\mathrm{tpenaH})\right]^{2+}$ and a hydroxyl radical. Both are aggressive hydrogen-atom abstractors and will react with methanol, benzyl alcohol, and hydrogen peroxide to form the methanoyl, benzoyl, and hydroperoxide $\left({ }^{\circ} \mathrm{CH}_{2} \mathrm{OH}, \mathrm{C}_{6} \mathrm{H}_{5}{ }^{\circ} \mathrm{CHOH},{ }^{\circ} \mathrm{OOH}\right)$ radicals, respectively. In turn, these radicals will propagate chain reactions and radical terminations to give the detected products, $\mathrm{CH}_{2} \mathrm{O}, \mathrm{C}_{6} \mathrm{H}_{5} \mathrm{CHO}$, and $\mathrm{O}_{2}$. Interconnected catalytic cycles for $\mathrm{H}_{2} \mathrm{O}_{2}$ disproportionation and alcohol oxidation are proposed in Scheme 6.

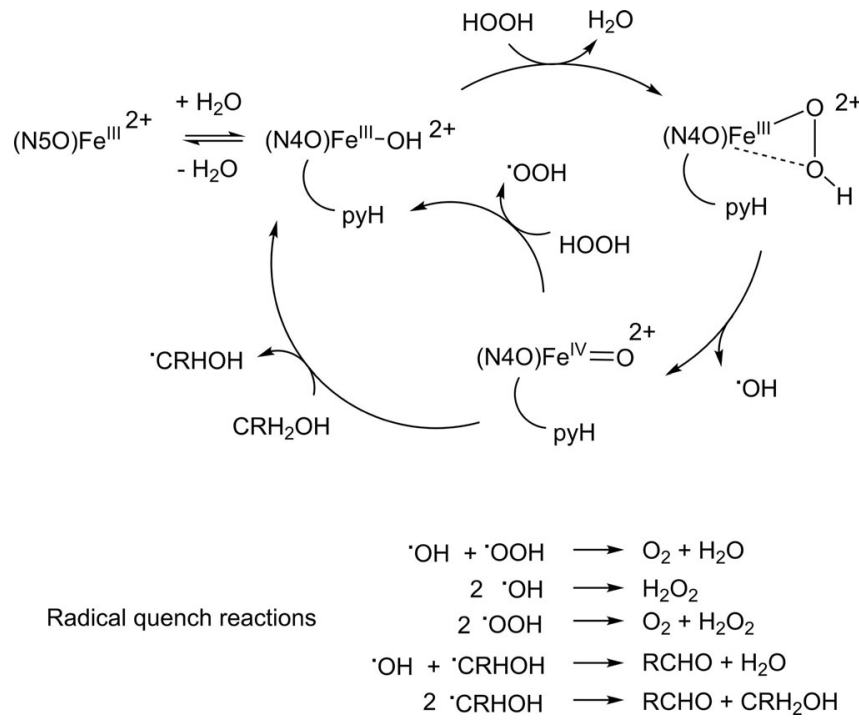

Scheme 6. Connected catalytic cycles for $\mathrm{H}_{2} \mathrm{O}_{2}$ disproportionation and $\mathrm{O}_{2}$ evolution, as well as methanol $(R=H)$ and benzyl alcohol $\left(R=\mathrm{C}_{6} \mathrm{H}_{5}\right)$ oxidation by $\mathrm{H}_{2} \mathrm{O}_{2}$.

\section{Perspective on the tunability by varying the supporting ligand in $\mathrm{H}_{2} \mathrm{O}_{2}$ activation by non-heme iron complexes}

Compared to analogous iron(III)-hydroperoxide complexes based on supporting N5 and N6 ligands containing exclusively pyridine and tertiary amine donors (Scheme $2 \mathrm{a}$ ) and analogous $\mathrm{N}, \mathrm{N}$-bis(2-pyridylmethyl)-N-bis(2-pyridyl)methylamine ${ }^{[37]}$ (N4py) systems, the influence of a biomimetic carboxylato donor is demonstrated by the significant difference in $\mathrm{Fe}^{\mathrm{III}} / \mathrm{Fe}$ " redox potentials of the parent $[\mathrm{Fe}(\mathrm{tpen})]^{3+}$ and $\left[\mathrm{Fe}(\text { tpena) }]^{2+}\right.$ complexes. The latter is shifted to lower values by an average of $360 \mathrm{mV}$ for the diastereoisomers in acetonitrile. A practical consequence of the lower redox potential is that tpena-Fe"ll complexes are isolated, and these are redox-stable in the +3 oxidation state in all solvents examined. ${ }^{[20,21]}$ This result stands in contrast to observations for the complexes of tpen and related N5 neutral pentadentate ligands (Scheme 2a), for which the iron(II) complexes are those most readily isolated, especially in solvents such as acetonitrile. These are thermodynamic sinks, 
retarding their reactivity with $\mathrm{H}_{2} \mathrm{O}_{2}$. This tendency towards greater stability in higher iron oxidation states will have a significant impact on the chemistry of the iron-tpena complexes and hence on the construction of proposed catalytic cycles. The pro-catalyst and resting state is iron(III) and not iron(II). As such, the process of peroxide adduct formation does not require a prior oxidation step from iron(II) to iron(III). The $\mathrm{Fe}^{\mathrm{IV} /}$ Fe'II couple can be reasonably expected to follow this trend towards lower potentials, ${ }^{[38]}$ and this will favour promotion of the homolytic cleavage of the $\mathrm{Fe}^{\mathrm{III}} \mathrm{O}-\mathrm{OH}$ bond in the hydroperoxide adduct to readily attain an iron(IV) oxo species. This is manifested in significantly shorter lifetimes for $[\mathrm{Fe}(\mathrm{OOH})(\mathrm{tpenaH})]^{2+}$ and $[\mathrm{Fe}(\mathrm{OO})(\mathrm{tpenaH})]^{+}$compared to the corresponding systems based on N5/N6 Rtpen ligands. A further contrast to the $\mathrm{N} 5 / \mathrm{N} 6$ donor-supported systems for the reaction of $\mathrm{H}_{2} \mathrm{O}_{2}$ with the resting state iron(III) in $\left[\mathrm{Fe}(\text { tpena) }]^{2+}\right.$ is that no deprotonation of the $\mathrm{H}_{2} \mathrm{O}_{2}$ is needed. It is an addition reaction accompanied by charge separation due to concomitant pyridine decoordination and pyridinium formation. The ligand is converted from monoanionic hexadentate (tpena) to zwitteranionic pentadentate (tpenaH). With one carboxylato donor and a second base in the coordination sphere, $[\mathrm{Fe}(\mathrm{OOH})(\mathrm{tpenaH})]^{2+}$ and its conjugate base $[\mathrm{Fe}(\mathrm{OO})(\mathrm{tpenaH})]^{+}$are particularly germane biomimics for non-heme iron(III) peroxides. The peroxide activation chemistry that we have observed is pertinent to elucidating mechanisms for $\mathrm{O}_{2}$-activating enzymes in which $\mathrm{Gly} /$ Asp groups are coordinated to the $\mathrm{O}_{2}$-binding site on iron. ${ }^{[9]}$ In particular, we note that the non-heme $1 \mathrm{Asp} / 3 \mathrm{His}$-coordinated iron superoxide dismutase ${ }^{[39]}$ evolves $\mathrm{O}_{2}$ in a similar manner to the Fe-tpena system studied here (although the disproportionated substrate is $\mathrm{O}_{2}^{--}$and not $\mathrm{H}_{2} \mathrm{O}_{2}$ ). The basic amino acid residues found in the second coordination sphere of non-heme active sites are proposed to facilitate proton-coupled redox reactions, and a similar role for the dangling pyridine/pyridinium groups of the tpena system is feasible.

The contrast in peroxide activation reactivity between [Fe(tpena) $]^{2+}$ and the parent pentadentate $\mathrm{N} 4 \mathrm{O}$ Rbpena-based Fe"ll systems (Scheme $2 \mathrm{~b}$ ) described in the Introduction is also worth noting: ligand oxygenations result from reactions of the iron(III) starting complexes with $\mathrm{H}_{2} \mathrm{O}_{2}$, without the detection of intermediate peroxide adducts (Scheme $2 \mathrm{~b}$ ). The two types of $\mathrm{O}$ atom insertions observed are consistent with heterolytic $\mathrm{O}$ O cleavage of a putative (Rbpena)Fe $\mathrm{e}^{\text {III }} \mathrm{O}-\mathrm{O}(\mathrm{H})$ intermediate to form a putative $\mathrm{Fe}^{\mathrm{v}}$ oxo species. This reactive species can then transfer [O] to the aromatic $\mathrm{C}-\mathrm{H}$ or $\mathrm{N}$ in bzbpena and mebpena, respectively. The iron(III) complexes of the modified "RbpenaO" ligands may be unable to activate $\mathrm{H}_{2} \mathrm{O}_{2}$, and are therewith stable towards oxidative decomposition, in contrast to the iron complex of tpena. ${ }^{[18]}$ Interestingly, the manganese complexes of Rbpena and tpena can withstand thousands of equivalents of organic peroxides without decomposition or ligand modification. ${ }^{[26,28]}$

\section{Conclusions}

Methanol oxidation to formaldehyde and stoichiometric yields of benzaldehyde from the $\left[\mathrm{Fe}(\text { tpena) }]^{2+}\right.$-catalysed oxidation of benzyl alcohol by $\mathrm{H}_{2} \mathrm{O}_{2}$ have been realized in the present study. In the absence of a large excess of a second substrate, $\mathrm{H}_{2} \mathrm{O}_{2}$ disproportionation is catalysed by [Fe(tpena) $]^{2+}$ through a related mechanism. However, in the absence of other oxidizable substrates (methanol, benzyl alcohol, and $\mathrm{H}_{2} \mathrm{O}_{2}$ ), oxidative decay of [Fe(tpena) $]^{2+}$ occurs through the spectroscopically detectable intermediate $[\mathrm{Fe}(\mathrm{OOH})(\mathrm{tpenaH})]^{2+}$. Release of all of the aliphatic carbon atoms and amine groups as $\mathrm{CO}_{2}$ and $\mathrm{NH}_{3}$, respectively, has been demonstrated. The reactivity patterns observed (catalysis of the oxidation of alcohols, catalase activity, and tpena degradation, Scheme 3) reflect the higher $\mathrm{C}-\mathrm{H}$ bond strength in $\mathrm{MeCN}$ compared to $\mathrm{MeOH}$, the aliphatic $\mathrm{C}-\mathrm{H}$ bonds in tpena, and the $\mathrm{O}-\mathrm{H}$ bond in $\mathrm{H}_{2} \mathrm{O}_{2}$, respectively. Overall, the $\mathrm{H}_{2} \mathrm{O}_{2}$ activation chemistry described here stands in contrast to that reported previously for the pentadentate N5 supporting ligands $\left[\mathrm{Fe}^{\text {III }}(\mathrm{OOH})(\mathrm{Rtpen})\right]^{2+}$ and $\left[\mathrm{Fe}^{\prime \prime \prime}(\mathrm{OOH})(\mathrm{N} 4 \mathrm{py})\right]^{2+}$ and a carboxylate-containing $\mathrm{N} 4 \mathrm{O}$ pentadentate supporting ligand [Fe"'(OOH)(Rbpena) $]^{2+}$. We have shown: 1) facile homolytic Fe"l'O-OH cleavage in solution to produce two aggressive $\mathrm{H}$-atom abstractors, $\mathrm{Fe}^{\mathrm{IV}}=\mathrm{O}$ and $\mathrm{HO}$; 2) catalytic $\mathrm{H}_{2} \mathrm{O}_{2}$ disproportionation, 3) catalytic alcohol oxidation with stoichiometric yields, and 4) total destruction of the aliphatic part of tpena in the presence of low concentrations of $\mathrm{H}_{2} \mathrm{O}_{2}$. By tuning the penta- and hexadentate ethylenediamine-backboned ligands (Scheme 2), a tendency towards the limiting reaction types depicted in Equations (2), (3), and (4) for Fe'II-peroxide adducts has been exposed. It seems that $\mathrm{H}_{2} \mathrm{O}_{2}$ activation is more effective for the carboxylato ligands and the difference in reactivity seen for the N4O (Rbpena) and N5O (tpena) ligand systems must be due to the availability of a second base in the coordination sphere for the latter. The proximity of this group suggests that it may participate at many stages, from its decoordination to allow adduct formation by charge-separated $\mathrm{H}_{2} \mathrm{O}_{2}$ addition to $\mathrm{H}$-bonding in the peroxide intermediates. In turn, this electronic modulation may effect a homolytic O-O cleavage rather than the heterolytic cleavage and intramolecular oxygenation that occurs with the otherwise stereochemically and electronically similar N4O Rbpena as a supporting ligand.

\section{Dissociation:}

$\left[\mathrm{Fe}^{\mathrm{III}}(\mathrm{OOH})(\text { Rtpen })\right]^{2+}+\mathrm{HX} \rightleftharpoons\left[\mathrm{Fe}^{\mathrm{III}}(\mathrm{X})(\text { Rtpen })\right]^{2+}+\mathrm{HOOH}$

O-O heterolysis:

$\left[\mathrm{Fe}^{\mathrm{II \prime}}(\mathrm{OOH})(\mathrm{Rbpena})\right]^{2+} \rightarrow\left[\mathrm{Fe}^{\mathrm{II \prime}}(\mathrm{RbpenaO})\right]^{2+}+\mathrm{OH}^{-}$

O-O homolysis:

$\left[\mathrm{Fe}^{\text {III }}(\mathrm{OOH})(\text { tpenaH })\right]^{2+} \rightarrow\left[\mathrm{Fe}^{\mathrm{IV}}(\mathrm{O})(\text { tpenaH })\right]^{2+}+\mathrm{OH}^{\cdot}$

Our work not only presents a germane mimic for non-heme iron chemistry, especially in terms of the carboxylato group and the second coordination sphere base, but also adds to our knowledge of the ligand design features important for activating $\mathrm{H}_{2} \mathrm{O}_{2}$, demonstrates controllable bifurcation in catalysed external substrate oxidation reactions, and indicates that destruc- 
tive oxidation of the supporting ligand can be avoided through appropriate experimental design [Eqs. (2-4)].

\section{Experimental Section}

\section{Materials and preparations}

$N, N, N^{\prime}$-Tris-(2-pyridylmethyl)ethylenediamine- $N^{\prime}$-acetic acid (tpenaH) ${ }_{1}^{[40]}\left[(\right.$ tpenaH) $\mathrm{Fe}-\mathrm{O}-\mathrm{Fe}($ tpenaH $)]\left(\mathrm{ClO}_{4}\right)_{4}\left(\mathrm{H}_{2} \mathrm{O}\right)_{2,}{ }^{[20]} \quad[\mathrm{Fe}(\mathrm{Cl})-$ tpen $]\left(\mathrm{PF}_{6}\right)_{1}{ }^{[17]}[\mathrm{Fe}(\mathrm{Cl})$ metpen $\left.)\right]\left(\mathrm{PF}_{6}\right)_{1}{ }_{1}^{[17]}$ and $[\mathrm{Fe}($ tpen $)]\left(\mathrm{ClO}_{4}\right)_{2}{ }^{[41]}$ were prepared as described previously. $\left[{ }^{18} \mathrm{O}\right] \mathrm{H}_{2} \mathrm{O}$ was supplied by Rotem Industries Ltd., and all other chemicals were purchased from Sigma-Aldrich.

CAUTION!!! Perchlorate salts of metal complexes are potentially explosive and should be handled with caution in small quantities.

$[\mathrm{Fe}(\mathrm{OOH})(\text { tpenaH })]^{2+}$ and $[\mathrm{Fe}(\mathrm{OO})(\text { tpenaH })]^{+}:[($tpenaH $) \mathrm{Fe}-\mathrm{O}-\mathrm{Fe}-$ (tpenaH) $]\left(\mathrm{ClO}_{4}\right)_{4}\left(\mathrm{H}_{2} \mathrm{O}\right)_{2}$ was dissolved in acetonitrile and the solution was allowed to stand for $10 \mathrm{~min}$ until [(tpenaH)Fe-O-Fe(tpenaH) $]^{4+}$ had dehydrated to $[\mathrm{Fe}(\mathrm{tpena})]^{2+}$. This solution was then treated with 50 equiv of $\mathrm{H}_{2} \mathrm{O}_{2}(50 \%$ in water, $w / w)$ to give $[\mathrm{Fe}(\mathrm{OOH})$ $(\text { tpenaH) }]^{2+}$, and $[\mathrm{Fe}(\mathrm{OO})(\text { tpenaH })]^{+}$was formed by the subsequent addition of 30 equiv of $\mathrm{Et}_{3} \mathrm{~N}$.

$[\mathrm{Fe}(\mathrm{Cl})($ tpenaH $)]\left(\mathrm{ClO}_{4}\right)_{2} \cdot(\mathrm{EtOH}) \cdot 2\left(\mathrm{H}_{2} \mathrm{O}\right): \quad \mathrm{Fe}\left(\mathrm{ClO}_{4}\right)_{2} \cdot 6 \mathrm{H}_{2} \mathrm{O} \quad(773 \mathrm{mg}$, $1.7 \mathrm{mmol}$ ) was added to tpenaH (655 mg, $1.7 \mathrm{mmol}$ ) in acetonitrile $(5 \mathrm{~mL})$, water $(5 \mathrm{~mL})$, and ethanol $(5 \mathrm{~mL})$, and the mixture was adjusted to $\mathrm{pH} 3$ with $\mathrm{HCl}($ aq.). Upon slow evaporation of the volatiles, yellow crystals of $[\mathrm{Fe}(\mathrm{Cl})(\mathrm{tpenaH})]\left(\mathrm{ClO}_{4}\right)_{2} \cdot \mathrm{EtOH} \cdot 2 \mathrm{H}_{2} \mathrm{O}(702 \mathrm{mg}$, $54 \%)$ were deposited after two weeks. ESI-MS (MeCN): $m / z: 479.1$ $\left([\mathrm{Fe}(\mathrm{Cl})(\text { tpena}-2 \mathrm{H})]^{+}, 78 \%\right), 481.1\left([\mathrm{Fe}(\mathrm{Cl})(\text { tpena })]^{+}, 81 \%\right), 482.1$ $\left(\left[\mathrm{Fe}(\mathrm{Cl})(\text { tpenaH) }]^{+}, 100 \%\right) ; \mathrm{ESI}-\mathrm{MS}\left(\mathrm{H}_{2} \mathrm{O}\right): \mathrm{m} / \mathrm{z}: 446.1 \text { ([Fe(tpena) }\right]^{+}$, $34 \%), 454.1$ ([(tpena)Fe-O-Fe(tpena) $\left.]^{2+}, 100 \%\right), 463.1$ ([Fe(OH)(tpena) $\left.]^{+}, 85 \%\right)$; IR (KBr): $v=1610(\mathrm{C}=0, \mathrm{~s}), 1098 \mathrm{~cm}^{-1}\left(\mathrm{ClO}_{4}^{-}, \mathrm{vs}\right)$ elemental analysis calcd (\%) for $\mathrm{C}_{22} \mathrm{H}_{29} \mathrm{~N}_{5} \mathrm{O}_{12} \mathrm{Cl}_{3} \mathrm{Fe}([\mathrm{Fe}(\mathrm{Cl})$ (tpenaH)]$\left(\mathrm{ClO}_{4}\right)_{2} \cdot 2 \mathrm{H}_{2} \mathrm{O}$ : C 36.82, $\mathrm{H}$ 4.07, N 9.76; found: $\mathrm{C} 36.21, \mathrm{H} 3.65, \mathrm{~N}$ 9.27 .

\section{Instrumentation and methods}

UV/Vis spectra were recorded from solutions in $1 \mathrm{~cm}$ quartz cuvettes on either an Agilent 8453 spectrophotometer with a UNISOKU CoolSpeK UV USP-203 temperature controller or an Analytik Jena Specord S600 with a Quantum Northwest TC 125 temperature controller. Raman spectra were recorded from samples in $1 \mathrm{~cm}$ quartz cuvettes at either $532 \mathrm{~nm}$ ( $300 \mathrm{~mW}$ at source, Cobolt Lasers) as described previously ${ }^{[30]}$ or $691 \mathrm{~nm}$ (75 mW at sample, Ondax Lasers). The solutions were cooled with a Quantum Northwest TC 125 temperature controller and the spectra were obtained at $-30^{\circ} \mathrm{C}$. Data were recorded and processed using Solis (Andor Technology) with spectral calibration with respect to the Raman spectrum of MeCN/toluene (50:50, w/w). Baseline correction was performed for all spectra, and normalized to the solvent band at $750 \mathrm{~cm}^{-1}$. EPR spectra (X-band) were recorded on a Bruker EMX Plus CW spectrometer (mod. amp.: $10 \mathrm{G}$, attenuation: $10 \mathrm{~dB}$ ) on frozen solutions at $110 \mathrm{~K}$. In order to follow the decay of the iron species, the samples for measurements $(200 \mu \mathrm{L})$ were transferred to EPR tubes and frozen in liquid nitrogen at different times. The software packages eview4wr and esimX were used for simulation. ${ }^{[42]}{ }^{1} \mathrm{H}$ NMR $(400.12 \mathrm{MHz})$ spectra were recorded on a Bruker Avance III 400 spectrometer at ambient temperature. Chemical shifts are denoted relative to the residual solvent peak $\left(\mathrm{CD}_{3} \mathrm{CN}\right.$, $1.94 \mathrm{ppm})$. Mössbauer spectra were obtained with conventional constant acceleration spectrometers with sources of ${ }^{57} \mathrm{Co}$ in rhodium foil. The spectra were collected at $14 \mathrm{~K}$. Isomer shifts are given relative to that of $\alpha$-Fe at $295 \mathrm{~K}$. Infrared spectra (IR) were obtained on a Hitachi $270-30$ IR spectrometer from samples in $\mathrm{KBr}$ pellets. Head-space FTIR spectra were recorded from samples in sealed $1 \mathrm{~cm}$ quartz cuvettes on a JASCO FT-NIR/MIR-4600 spectrometer with a resolution of $8 \mathrm{~cm}^{-1}$. The concentration of $\mathrm{CO}_{2}$ released was quantified on the basis of standard solutions of $\mathrm{Na}_{2} \mathrm{CO}_{3}$ in water with addition of 3 equiv acid $(\mathrm{HCl})$ to force the release of $\mathrm{CO}_{2}$. Aliquots $(1 \mathrm{~mL})$ of the solution were placed in a sealed cuvette, and the head-space was monitored before and after the addition of acid. A standard curve based on the absorbance at $2360 \mathrm{~cm}^{-1}$ was fitted to $\left[\mathrm{CO}_{2}\right]<5 \mathrm{~mm}$ : Abs $\left(2360 \mathrm{~cm}^{-1}\right)=0.0300 \mathrm{~mm}^{-1 \cdot}\left[\mathrm{CO}_{2}\right]+$ 0.0084 and $\left[\mathrm{CO}_{2}\right]>5 \mathrm{~mm}$ : Abs $\left(2360 \mathrm{~cm}^{-1}\right)=0.0281 \mathrm{~mm}^{-1 \cdot}\left[\mathrm{CO}_{2}\right]+$ 0.0213. MIMS spectra were recorded using a Prisma quadrupole mass spectrometer (Pfeiffer Vacuum, Asslar, Germany). A flat sheet membrane $(250 \mu \mathrm{m})$ of polydimethyl siloxane (Sil-Tec sheeting, Technical Products, Decatur, GA, USA) separated the vacuum chamber $\left(1 \times 10^{-6} \mathrm{mbar}\right)$ from the solution in the sample chamber (total volume $2.5 \mathrm{~mL}$ ), which was stirred mechanically. The data were recorded and processed using Quadstar 422 (Pfeiffer Vacuum, Asslar, Germany). The reaction chamber was filled with a solution of [Fe(tpena) $]^{2+}$, and $\mathrm{H}_{2} \mathrm{O}_{2}$ was injected directly into the solution in the sample chamber as the resulting gas evolution was simultaneously measured. Electrospray ionization (ESI) mass spectra were recorded in high-resolution positive-ion mode on a Bruker microTOF-QII mass spectrometer. Single-crystal X-ray diffraction data were collected on a Rigaku R-AXIS IIC image-plate system $\left(\mathrm{Mo}_{\mathrm{K \alpha}}\right.$ radiation) at $100 \mathrm{~K}$. Cyclic voltammetry was performed on an Eco Chemie Autolab PGSTAT10 potentiostat/galvanostat using a standard threeelectrode set-up with a Pt disc as the working electrode, a Pt wire as the counter electrode, and $\mathrm{Ag} / \mathrm{Ag}^{+}$as the reference electrode $\left(0.01 \mathrm{M} \mathrm{AgNO}_{3}\right.$ in $0.1 \mathrm{M} \mathrm{TBAClO}_{4}$ in $\mathrm{MeCN}$; TBA: tert-butylammonium). The electrolyte was also $0.1 \mathrm{M} \mathrm{TBAClO}{ }_{4}$ in $\mathrm{MeCN}$. The working electrode was cleaned by polishing with $0.05 \mu \mathrm{m}$ alumina followed by sonication, and the solutions were purged with nitrogen prior to measurements. The oxidation potential of $\mathrm{Fc} / \mathrm{Fc}^{+}$against $\mathrm{Ag} /$ $\mathrm{Ag}^{+}$was measured as $0.08 \mathrm{~V}$, and all oxidation potentials were converted accordingly.

CCDC $1559278\left([\mathrm{Fe}(\mathrm{Cl})(\right.$ tpenaH $\left.)]\left(\mathrm{ClO}_{4}\right)_{2} \cdot(\mathrm{EtOH}) \cdot 2\left(\mathrm{H}_{2} \mathrm{O}\right)\right)$ contains the supplementary crystallographic data for this paper. These data are provided free of charge by The Cambridge Crystallographic Data Centre.

\section{Acknowledgements}

This work was supported by the Danish Council for Independent Research | Natural Sciences (grant 4181-00329 to C.McK.). C.W. thanks COST action CM1305 (ECOSTBio) for the travel grant STSM \#30679. Dr. Anne Nielsen, Dr. Anders Lennartson, and Dr. Mads Vad are acknowledged for some preliminary experimental work. Lars Brændegaard Hansen is thanked for designing the reaction cell for the MIMS setup.

\section{Conflict of interest}

The authors declare no conflict of interest.

Keywords: $\mathrm{H}_{2} \mathrm{O}_{2}$ activation - high-valent iron - hydroxyl radical $\cdot \operatorname{iron}(\mathrm{IV}) \cdot \mathrm{N}, \mathrm{O}$ ligands $\cdot$ peroxides

[1] B. Meunier, S. P. de Visser, S. Shaik, Chem. Rev. 2004, 104, 3947-3980. 
[2] J. H. Dawson, Science 1988, 240, 433-439.

[3] M. Costas, M. P. Mehn, M. P. Jensen, L. Que, Jr., Chem. Rev. 2004, 104, 939-986.

[4] S. Kal, L. Que, Jr., J. Biol. Inorg. Chem. 2017, 22, 339-365.

[5] W. Nam, Acc. Chem. Res. 2015, 48, 2415-2423.

[6] K. P. Bryliakov, E. P. Talsi, Coord. Chem. Rev. 2014, 276, 73-96.

[7] L. Que, Jr., W. B. Tolman, Nature 2008, 455, 333-340.

[8] W. Nam, Acc. Chem. Res. 2007, 40, 522-531.

[9] E. G. Kovaleva, J. D. Lipscomb, Nat. Chem. Biol. 2008, 4, 186-193.

[10] I. Bernal, I. M. Jensen, K. B. Jensen, C. J. Mckenzie, H. Toftlund, J.-P. Tuchagues, J. Chem. Soc. Dalton Trans. 1995, 3667-3675.

[11] K. B. Jensen, C. J. McKenzie, L. P. Nielsen, J. Z. Pedersen, H. M. Svendsen, Chem. Commun. 1999, 1313-1314.

[12] A. J. Simaan, F. Banse, P. Mialane, A. Boussac, S. Un, T. Kargar-Grisel, G. Bouchoux, J.-J. Girerd, Eur. J. Inorg. Chem. 1999, 993-996.

[13] P. Mialane, A. Nivorojkine, G. Pratviel, L. Azéma, M. Slany, F. Godde, A. Simaan, F. Banse, T. Kargar-Grisel, G. Bouchoux, J. Sainton, O. Horner, J. Guilhem, L. Tchertanova, B. Meunier, J.-J. Girerd, Inorg. Chem. 1999, 38, $1085-1092$.

[14] A. J. Simaan, S. Döpner, F. Banse, S. Bourcier, G. Bouchoux, A. Boussac, P. Hildebrandt, J.-J. Girerd, Eur. J. Inorg. Chem. 2000, 1627-1633.

[15] A. J. Simaan, F. Banse, J.-J. Girerd, K. Wieghardt, E. Bill, Inorg. Chem. $2001,40,6538-6540$.

[16] O. Horner, C. Jeandey, J.-L. Oddou, P. Bonville, C. J. McKenzie, J.-M Latour, Eur. J. Inorg. Chem. 2002, 3278-3283.

[17] A. Hazell, C. J. McKenzie, L. P. Nielsen, S. Schindler, M. Weitzer, J. Chem. Soc. Dalton Trans. 2002, 310-317.

[18] A. Nielsen, F. B. Larsen, A. D. Bond, C. J. McKenzie, Angew. Chem. Int. Ed. 2006, 45, 1602-1606; Angew. Chem. 2006, 118, 1632- 1636.

[19] a) J. Kaizer, E. J. Klinker, N. Y. Oh, J.-U. Rohde, W. J. Song, A. Stubna, J. Kim, E. Münck, W. Nam, L. Que, Jr., J. Am. Chem. Soc. 2004, 126, $472-$ 473; b) V. Balland, M.-F. Charlot, F. Banse, J.-J. Girerd, T. A. Mattioli, E. Bill, J.-F. Bartoli, P. Battioni, D. Mansuy, Eur. J. Inorg. Chem. 2004, 301-308 c) M. Martinho, F. Banse, J.-F. Bartoli, T. A. Mattioli, P. Battioni, O. Horner S. Bourcier, J.-J. Girerd, Inorg. Chem. 2005, 44, 9592-9596.

[20] A. Lennartson, C. J. McKenzie, Angew. Chem. Int. Ed. 2012, 51, 6767 6770; Angew. Chem. 2012, 124, 6871-6874.

[21] D. P. de Sousa, C. Wegeberg, M. S. Vad, S. Mørup, C. Frandsen, W. A. Donald, C. J. McKenzie, Chem. Eur. J. 2016, 22, 3810-3820.

[22] D. Angelone, D. Abdolahzadeh, J. W. de Boer, W. R. Browne, Eur. J. Inorg. Chem. 2015, 3532-3542.

[23] D. P. de Sousa, C. J. Miller, Y. Chang, T. D. Waite, C. J. McKenzie, Inorg. Chem. 2017, DOI: https://doi.org/10.1021/acs.inorgchem.7b02208.

[24] M. S. Vad, A. Lennartson, A. Nielsen, J. Harmer, J. E. McGrady, C. Frandsen, S. Mørup, C. J. McKenzie, Chem. Commun. 2012, 48, 10880-10882.

[25] D. P. de Sousa, J. O. Bigelow, J. Sundberg, L. Que, Jr., C. J. McKenzie, Chem. Commun. 2015, 51, 2802-2805.

[26] C. Deville, M. Finsel, D. P. de Sousa, B. Szafranowska, J. Behnken, S. Svane, A. D. Bond, R. K. Seidler-Egdal, C. J. McKenzie, Eur. J. Inorg. Chem 2015, 3543-3549.
[27] U. G. Nielsen, A. Hazell, J. Skibsted, H. J. Jakobsen, C. J. McKenzie, CrystEngComm 2010, 12, 2826-2834.

[28] a) A. K. Poulsen, A. Rompel, C. J. McKenzie, Angew. Chem. Int. Ed. 2005 44, 6916-6920; Angew. Chem. 2005, 117, 7076-7080; b) R. K. SeidlerEgdal, A. Nielsen, A. D. Bond, M. J. Bjerrum, C. J. McKenzie, Dalton Trans. 2011, 40, 3849-3858.

[29] T. Nebe, A. Beitat, C. Würtele, C. Dücker-Benfer, R. van Eldik, C. J. McKenzie, S. Schindler, Dalton Trans. 2010, 39, 7768-7773.

[30] S. K. Padamati, A. Draksharapu, D. Unjaroen, W. R. Browne, Inorg. Chem. 2016, 55, $4211-4222$

[31] A. Boffi, E. Chiancone, Biochemistry 1997, 36, 4505-4509.

[32] a) C. Deville, V. McKee, C. J. McKenzie, Dalton Trans. 2017, 46, 709-719; b) D. Pijper, P. Saisaha, J. W. de Boer, R. Hoen, C. Smit, A. Meetsma, R. Hage, R. P. van Summeren, R. L. Alsters, B. L. Feringa, W. R. Browne, Dalton Trans. 2010, 39, 10375-10381.

[33] T. Nash, Biochem. J. 1953, 55, 416-421.

[34] Y.-R. Luo, in Comprehensive Handbook of Chemical Bond Energies, CRC, Boca Raton, 2007, pp. 19-134.

[35] A control using [Fe(tpen)] ${ }^{2+}$ actually showed a decrease in the rate of benzyl alcohol oxidation compared to the non-catalysed reaction. This implies that the coordination of the hydroperoxide to form $[\mathrm{Fe}(\mathrm{OOH}) \mathrm{tp}$ en) $]^{2+}$ in fact results in a deactivation of $\mathrm{H}_{2} \mathrm{O}_{2}$, at least with respect to this particular reaction.

[36] A. Faponle, M. G. Quesne, C. V. Sastri, F. Banse, S. P. de Visser, Chem. Eur. J. 2015, 21, $1221-1236$

[37] a) M. Lubben, A. Meetsma, E. C. Wilkinson, B. Feringa, L. Que, Jr., Angew. Chem. Int. Ed. Engl. 1995, 34, 1512-1514; Angew. Chem. 1995, 107 1610-1612; b) G. Roelfes, M. Lubben, K. Chen, R. Y. N. Ho, A. Meetsma, S. Genseberger, R. M. Hermant, R. Hage, S. K. Mandel, V. G. Young, Jr., Y. Zang, H. Kooijman, A. L. Spek, L. Que, Jr., B. L. Feringa, Inorg. Chem. 1999, 38, 1929-1936.

[38] Although not directly comparable, we have observed the oxidation of $\left[(\text { tpenaH }) \mathrm{Fe}^{\prime \prime \prime}(\mu-\mathrm{O}) \mathrm{Fe}^{\prime \prime \prime \prime}(\text { tpenaH })\right]^{4+}$ in water to give $\left[\mathrm{Fe}^{\mathrm{IV}}(\mathrm{O})-(\mathrm{tpenaH})\right]^{2+}$ to occur at around $500-670 \mathrm{mV}$ versus the NHE in the $\mathrm{pH}$ range $7-2$, respectively. See reference [23].

[39] M. S. Lah, M. M. Dixon, K. A. Pattridge, W. C. Stallings, J. A. Fee, M. L. Ludwig, Biochemistry 1995, 34, 1646-1660.

[40] J. Glerup, P. A. Goodson, A. Hazell, R. Hazell, D. J. Hodgson, C. J. McKenzie, K. Michelsen, U. Rychlewska, H. Toftlund, Inorg. Chem. 1994, 33, 4105-4111.

[41] H.-R. Chang, J. K. McCusker, H. Toftlund, S. R. Wilson, A. X. Trautwein, H. Winkler, D. N. Hendrikson, J. Am. Chem. Soc. 1990, 112, 6814-6827.

[42] E. Bill 2016, Max-Planck-Institute for Chemical Energy Conversion, Mülheim; available from the author by mail to: eckhard.bill@cec.mpg.de.

Manuscript received: September 29, 2017

Accepted manuscript online: October 30, 2017

Version of record online: 口u, 0000 


\section{FULL PAPER}

Peroxide activation at Fe: A transient $\mathrm{Fe}^{\text {III-hydroperoxide intermediate has }}$ been spectroscopically identified during [Fe"l'(tpena) $]^{2+}$-catalysed $\mathrm{H}_{2} \mathrm{O}_{2}$ disproportionation in acetonitrile (see graphic). If benzyl alcohol is present, or methanol is used as solvent, $\mathrm{H}_{2} \mathrm{O}_{2}$ disproportionation is inhibited in favour of high-yielding alcohol oxidation to the corresponding aldehyde. In the absence of excess substrate (alcohol or $\mathrm{H}_{2} \mathrm{O}_{2}$ ), tpena is oxidatively degraded.

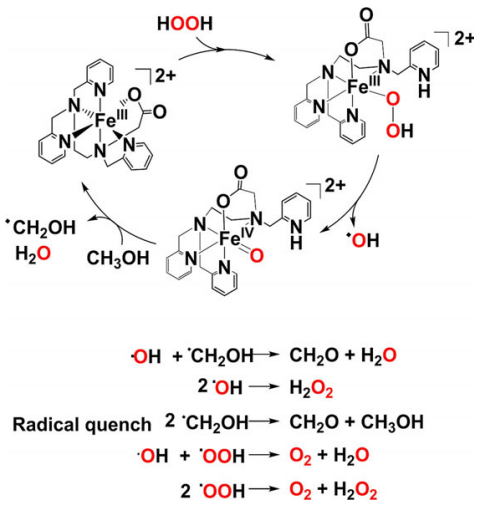

Coordination Chemistry

C. Wegeberg, F. R. Lauritsen, C. Frandsen, S. Mørup, W. R. Browne, C. J. McKenzie*

Directing a Non-Heme Iron(III)Hydroperoxide Species on a Trifurcated Reactivity Pathway 